$$
\text { DOE/PC/89652--TIY }
$$

INNOVATIVE CLEAN COAL TECHNOLOGY (ICCT)

\title{
DEMONSTRATION OF SELECTIVE CATALYTIC REDUCTION (SCR) TECHNOLOGY FOR THE CONTROL OF NITROGEN OXIDE (NO) EMISSIONS FROM HIGH-SULFUR COAL-FIRED BOILERS
}

\section{Technical Progress Report}

Fourth Quarter 1993

June 1995

DOE Contract

DE-FC22-90PC89652

SCS Contract

C-91-000026

Prepared by:

Southern Company Services, Inc.

800 Shades Creek Parkway

Birmingham, Alabama 35209

Cleared by DOE Patent Council on July 12, 1995 


\section{DISCLAIMER}

Portions of this document may be illegible in electronic image products. Images are produced from the best available original document. 


\section{LEGAL NOTICE}

This report was prepared by Southern Company Services, Inc. pursuant to a cooperative agreement partially funded by the U. S. Department of Energy and neither Southern Company Services, Inc. nor any of its subcontractors nor the U. S. Department of Energy, nor any person acting on behalf of either:

(a) Makes any warranty or representation, express or implied with respect to the accuracy, completeness, or usefulness of the information contained in this report, or that the use of any information, apparatus, method, or process disclosed in this report may not infringe privately-owned rights; or

(b) Assumes any liabilities with respect to the use of, or for damages resulting from the use of, any information, apparatus, method or process disclosed in this report.

Reference herein to any specific commercial product, process, or service by trade name, trademark, manufacturer, or otherwise, does not necessarily constitute or imply its endorsement, recommendation, or favoring by the U. S. Department of Energy. The views and opinion of authors expressed herein do not necessarily state or reflect those of the U. S. Department of Energy. 
Section 1

SUMMARY

The objective of this project is to demonstrate and evaluate commercially available Selective Catalytic Reduction (SCR) catalysts from U. S., Japanese and European catalyst suppliers on a high-sulfur U. S. coal-fired boiler. SCR is a post-combustion nitrogen oxide $\left(\mathrm{NO}_{\mathrm{x}}\right)$ control technology that involves injecting ammonia into the flue gas generated from coal combustion in an electric utility boiler. The flue gas containing ammonia is then passed through a reactor that contains a specialized catalyst. In the presence of the catalyst, the ammonia reacts with $\mathrm{NO}_{\mathrm{x}}$ to convert it to nitrogen and water vapor.

Although SCR is widely practiced in Japan and Europe on gas-, oil-, and low-sulfur coal-fired boilers, there are several technical uncertainties associated with applying SCR to U. S. coals. These uncertainties include:

(1) potential catalyst deactivation due to poisoning by trace metal species present in U.S. coals that are not present in other fuels.

(2) performance of the technology and effects on the balance-of-plant equipment in the presence of high amounts of $\mathrm{SO}_{2}$ and $\mathrm{SO}_{3}$. performance of a wide variety of SCR catalyst compositions, geometries and methods of manufacture under typical high-sulfur coal-fired utility operating conditions.

These uncertainties are being explored by operating a series of small-scale SCR reactors and simultaneously exposing different SCR catalysts to flue gas derived from the combustion of high sulfur U. S. coal.

The demonstration is being performed at Gulf Power Company's Plant Crist Unit No. 5 (75 MW capacity) near Pensacola, Florida. The project is funded by the U. S. Department of Energy (DOE), Southern Company Services, Inc. (SCS on behalf of the entire Southern electric system), the Electric Power Research Institute (EPRI), and Ontario Hydro. SCS is the participant responsible for managing all aspects of this project.

The project is being conducted in the following three phases: 
Phase I - Permitting, Environmental Monitoring Plan and Preliminary Engineering

Phase II - Detailed Design Engineering and Construction

Phase III - Operation, Testing, Disposition and Final Report

The preliminary parametric test sequences for the three large reactors $(\mathrm{A}-\mathrm{C})$ were completed the previous quarter. During this fourth quarter of 1993, the large reactors were operated in longterm base operating conditions, i.e. at an ammonia/ $\mathrm{NO}_{\mathrm{x}}$ ratio near 0.83 for $80 \% \mathrm{NO}_{\mathrm{x}}$ removal. The parametric tests for Reactors D - F were completed after an operational shakedown period consisting of recalibration of the venturi and ammonia mass flow controllers on each of the reactors, as well as a check-out of the gas analysis equipment. Although parametric testing was initiated, testing was interrupted and not completed on Reactors G - J. (The reasons for this incomplete testing are discussed later.) By the end of December 1993, the total number of operating hours with exposure to flue gas on the reactors ranged from 408 for Reactor $\mathrm{G}$ to 3568 for Reactor B. The catalyst vendors, assigned reactors, and total number of operating hours with exposure to flue gas are shown below:

$\begin{array}{lccc}\text { Catalyst supplier } & \text { Reactor designation } & & \text { Operating hours } \\ \text { W. R. Grace } & \text { A (large) } & 2666 \\ \text { Nippon Shokubai } & \text { B (large) } & 3568 \\ \text { Siemens } & \text { C (large) } & 3517 \\ \text { W. R. Grace } & \text { D (small) } & 1891 \\ \text { Cormetech } & \text { E (small) } & 1891 \\ \text { Haldor Topsoe } & \text { F (small) } & 1891 \\ \text { Hitachi Zosen } & \text { G (small) } & \\ \text { Engelhard } & \text { H (small) } & 408 \\ \text { Engelhard } & \text { J (small) } & 917 \\ \end{array}$

The test facility experienced several outages during October. Two outages were a result of the Unit 5 boiler being forced off-line. The test facility operators used these times to clean fans and inspect the cyclones for plugging. A scheduled test facility outage occurred over a Saturday to replace the service water bypass valve with an upgraded version. Also, failure of one of the control system's analog input cards forced the small reactors to be taken off-line part of a day while manual overrides kept the large reactors on-line until the card was replaced. 
There was a planned outage during the first week of November, during which the first catalyst samples were retrieved from the three large reactors and sent to the catalyst suppliers for laboratory testing. Upon inspection, the top catalyst bed on Reactor $\mathrm{C}$ was found to be damaged by the sootblower rake twisting in the reactor and physically striking the catalyst modules. At the end of December during the next outage for catalyst sampling, the catalyst in reactor $C$ which had been previously damaged by physical contact with the sootblower, was replaced. (Although this catalyst had been physically damaged, there had been no previous indication operationally $\left[\mathrm{NO}_{\mathrm{x}}\right.$ removal and pressure drop] that this damage was happening. Thus, although damaged, the catalyst was still yielding excellent $\mathrm{NO}_{\mathrm{x}}$ reduction performance.) The reactor sootblowers were inspected and repaired as needed, with most having their rake covers trimmed for clearance and all fitted with an external anti-rotation device to prevent a similar occurrence as previously experienced on Reactor C.

During the early November catalyst sampling on the three large reactors, the dummy bed on Reactor A was discovered to be heavily eroded and plans were made to replace the dummy bed. This dummy bed replacement was accomplished in late December. The dummy bed in Reactor D was also replaced since it was the same material as that originally in Reactor A. Otherwise, the dummy beds and catalyst baskets had little apparent damage or erosion and were relatively clean regarding fouling from ash.

During an outage over the Thanksgiving holiday, the plate catalyst in Reactor G was inspected due to a large increase in pressure drop noticed prior to the outage. About half the catalyst elements were found to be severely damaged. All but two of the nine reactor catalysts are sampled directly from the actual catalyst beds. However in Reactors F and G, the catalyst is a monolithic plate structure which prohibits samples being pulled directly from the catalyst bed. In these two reactors, catalyst coupons were mounted above each catalyst bed for catalyst sampling purposes (also at the outlet of the last bed in Reactor F). It appears that the air sootblowing procedures destroyed the coupons, and in Reactor G, the coupons subsequently fell down and damaged the main catalyst layers. The catalyst supplier provided replacement catalyst elements for installation in the first quarter of 1994 and the air sootblowing procedure was changed. Per the vendor's advice, this catalytic reactor will be operated in the future without sootblowing. Operation of this reactor ceased until the catalyst is replaced early in 1994.

During the holidays at the end of December, there was a planned outage for catalyst sampling and facility modifications. Reactors A - F were inspected and catalyst samples taken and sent to 
the suppliers for laboratory analysis. The only catalyst sampling coupons present for the December sampling in Reactor $F$ were those at the reactor exit, and there were no coupons for Reactor G.

Laboratory analysis had begun by the catalyst suppliers on the catalyst samples taken after one quarter of operation on the three large reactors. Upon completion of the initial parametric testing in early December, base-line ammonia slip measurements were repeated. These tests were completed during December and the results indicated all catalysts were performing well with less than 2 ppm slip under base-line conditions, and in many cases the measured slip was below the 1 ppm detection limit.

The gas sampling/monitoring issues reported for the previous quarter continued to be addressed during this quarter. These problems included coordinating the time-shared analyzers and communicating with the test facility's data collection system. These items were successfully resolved by the end of this quarter.

In addition to the above problems, significant dilution effects due to air in-leakage into the reactor were also creating apparent data anomalies. The $\mathrm{NO}_{\mathrm{x}}$ concentration inputs for automatic ammonia injection were taken from the inlet ductwork to the pilot plant, rather than from the ammonia injection point. Therefore, air in-leakage after the sample point decreased the $\mathrm{NO}_{\mathrm{x}}$ concentration at the ammonia injection point. This skewed the calculation for ammonia injection rate and resulted in a higher than expected ammonia-to- $\mathrm{NO}_{\mathrm{x}}$ ratio. Of course, the ammonia injection rate can easily be corrected by material balance to compensate for oxygen in-leakage. This, however, links a large number of continuous measurements to the calculation, resulting in frequent errors when one of the measurement points is not operating correctly. To avoid similar problems in the future, $\mathrm{NO}_{\mathrm{x}}$ readings should be taken close to the ammonia injection point, rather than upstream of potential in-leakage sources.

Problems previously experienced with $\mathrm{NO}_{\mathrm{X}}$ measurements in the presence of ammonia, apparently with catalytic reactions proceeding in the sampling system, thus reducing $\mathrm{NO}_{\mathrm{x}}$ before the sample reaches the analyzers, continued. There has been a series of traps and filters previously installed in the sample line to capture the ash, water vapor and acid condensate in order to improve the accuracy of the analyzer system. The original dilution probe, made of Inconel, for measuring $\mathrm{NO}_{x}$ at intermediate levels in the reactors appeared to produce up to $30 \%$ $\mathrm{NO}_{\mathrm{x}}$ reduction in the presence of ammonia, thus giving low $\mathrm{NO}_{\mathrm{x}}$ readings at the analyzer. In 
December 1993, after modifying the probe with 316 SS, the probe was re-tested with and without ceramic probe tips. The results were still the same, with or without the ceramic probe tips, i.e., about $30 \% \mathrm{NO}_{\mathrm{x}}$ reduction across the probe. Work continued to resolve this issue with plans formulated to evaluate a glass-lined tip early in 1994.

Precision mass flow control valves supplied by Sierra Instrumentation were installed to control the ammonia vapor flow rates for injection into the reactors. These controllers were affected by liquid in the flow stream, pressure variations, trash in the line, and also the orientation of the controller itself. Although initial results indicated accurate flow control, subsequent measurements indicated that actual ammonia flow was 10 to 25 percent higher than the controllers were indicating. Previous actions taken to correct this situation included installing coalescent filters on the ammonia supply lines to each control valve, reorienting the controllers, replacing the ammonia header pressure regulator, cleaning each controller, and recalibrating and verifying with other instruments.

After the above changes, the results for the controllers on the large reactors were still unacceptable. During this quarter, one of the current ammonia flow controllers was replaced with another vendor's controller (Brooks) for a trial period of two months. The evaluation was concluded in December and based on the better performance of the Brooks' equipment, the decision was made to replace the original ammonia flow controllers for the large reactors.

In addition to the inleakage and ammonia flow problems mentioned above, there was another issue which, combined with these two issues, affected the actual ammonia-to- $\mathrm{NO}_{\mathrm{x}}$ ratio. During this quarter, the portion of flue gas $\mathrm{NO}_{\mathrm{x}}$ concentration as $\mathrm{NO}_{2}$ was only $1 \%$. However, the ammonia-to- $\mathrm{NO}_{\mathrm{x}}$ theoretically required quantity was based on $5 \%$ of the $\mathrm{NO}_{\mathrm{x}}$ being $\mathrm{NO}_{2}$. Based on this and the inleakage problem, the ammonia-to- $\mathrm{NO}_{\mathrm{x}}$ ratio was normally set at near 0.76 to result in an effective ammonia-to- $\mathrm{NO}_{\mathrm{x}}$ of 0.81 , giving a $\mathrm{NO}_{\mathrm{x}}$ reduction of $80 \%$. Due to calibration problems in the ammonia injection system and calibration drift, the long-term effective ammonia-to- $\mathrm{NO}_{\mathrm{x}}$ ratio was about 0.9 during the first two quarters of testing.

The above issues were the reasons there were rather limited long-term operating data during this period.

As reported in the previous progress report, the low-dust reactor, Reactor J, experienced severe plugging of the first catalyst layer after only a few hours of operation during its first start-up after 
catalyst loading. The first layer catalyst element was returned to the catalyst vendor for examination and a study undertaken to evaluate solutions to prevent recurrence of this problem. The resulting design changes previously approved to prevent recurrence of the plugging problem on the low dust reactor included the following: the reactor isolation and purge dampers should be relocated to minimize the deadleg; and the reactor heater capacity would be increased and the heater moved to just downstream of the isolation damper to raise the minimum gas temperature throughout the entire length of ductwork between the scoop and reactor inlet. During the fourth quarter of 1993, these changes were implemented at the test facility.

However, prior to restarting Reactor J, Engelhard cited commercial reasons for withdrawing from the project. Thus, operation of both Reactors $\mathrm{H}$ and $\mathrm{J}$ were ceased temporarily because of this decision. Solicitation, evaluation, and selection of catalyst replacements are to be performed during the next reporting period.

A project review meeting was held for all involved parties on December 8-9 at Plant Crist in which general progress since September 1993 was discussed, and specific vendor data were discussed in separate meetings with each vendor.

Data has been collected for ammonia/ $\mathrm{NO}_{\mathrm{x}}$ ratios, flue gas temperatures, air heater performance data, and catalyst specific performance parameters (reactor pressure drop, $\mathrm{NO}_{\mathrm{x}}$ reduction, ammonia slip, and $\mathrm{SO}_{2}$ oxidation). (Please see Task 1.3.2 - Process Evaluation under PROJECT STATUS). 
Section 2

INTRODUCTION

The Innovative Clean Coal Technology (ICCT) Program is designed to demonstrate clean coal technologies that are capable of retrofitting or repowering existing facilities to achieve significant reduction in sulfur dioxide $\left(\mathrm{SO}_{2}\right)$ and/or nitrogen oxides $\left(\mathrm{NO}_{\mathrm{x}}\right)$ emissions. The technologies selected for demonstration are capable of being commercialized in the 1990s and are expected to be more cost effective than current technologies.

This ICCT project is jointly funded by the U. S. Department of Energy, the Electric Power Research Institute (EPRI), Ontario Hydro, and by Southern Company Services (SCS) on behalf of the entire Southern electric system. The project's objective is to demonstrate the selective catalytic reduction (SCR) process that removes nitrogen oxides $\left(\mathrm{NO}_{\mathrm{x}}\right)$ from the flue gas of boilers that burn U.S. high-sulfur coal. The SCR technology involves the injection of $\mathrm{NH}_{3}$ into the flue gas and the subsequent catalytic reduction of $\mathrm{NO}_{x}$ by $\mathrm{NH}_{3}$ to produce molecular nitrogen $\left(\mathrm{N}_{2}\right)$ and water vapor.

A simplified SCR process flow diagram with major equipment is shown in Figure 1. Specifically, hot flue gas leaving the economizer section of the boiler is ducted to the SCR reactor. Prior to entering the reactor, $\mathrm{NH}_{3}$ is injected into the flue gas at a sufficient distance upstream of the reactor to provide for complete mixing of the $\mathrm{NH}_{3}$ and flue gas. The quantity of $\mathrm{NH}_{3}$ can be adjusted and it reacts with the $\mathrm{NO}_{\mathbf{x}}$ from the flue gas. The flue gas leaving the catalytic reactor enters the air preheater where it transfers heat to the incoming combustion air. Provisions are made for ash removal from the bottom of the reactor since some fallout of fly ash is expected. Duct work is also provided to bypass some flue gas around the economizer during periods when the boiler is operating at reduced load. This is done to maintain the temperature of the flue gas entering the catalytic reactor at the proper reaction temperature of about $700^{\circ} \mathrm{F}$. The flue gas leaving the air preheater goes to the electrostatic precipitator (ESP) where fly ash is removed. The ESP is part of the existing plant and is generally unaffected by the SCR system except as higher $\mathrm{SO}_{3}$ content affects the electrical resistivity of the fly ash or if $\mathrm{NH}_{4} \mathrm{HSO}_{4}$ coprecipitates with the fly ash. 


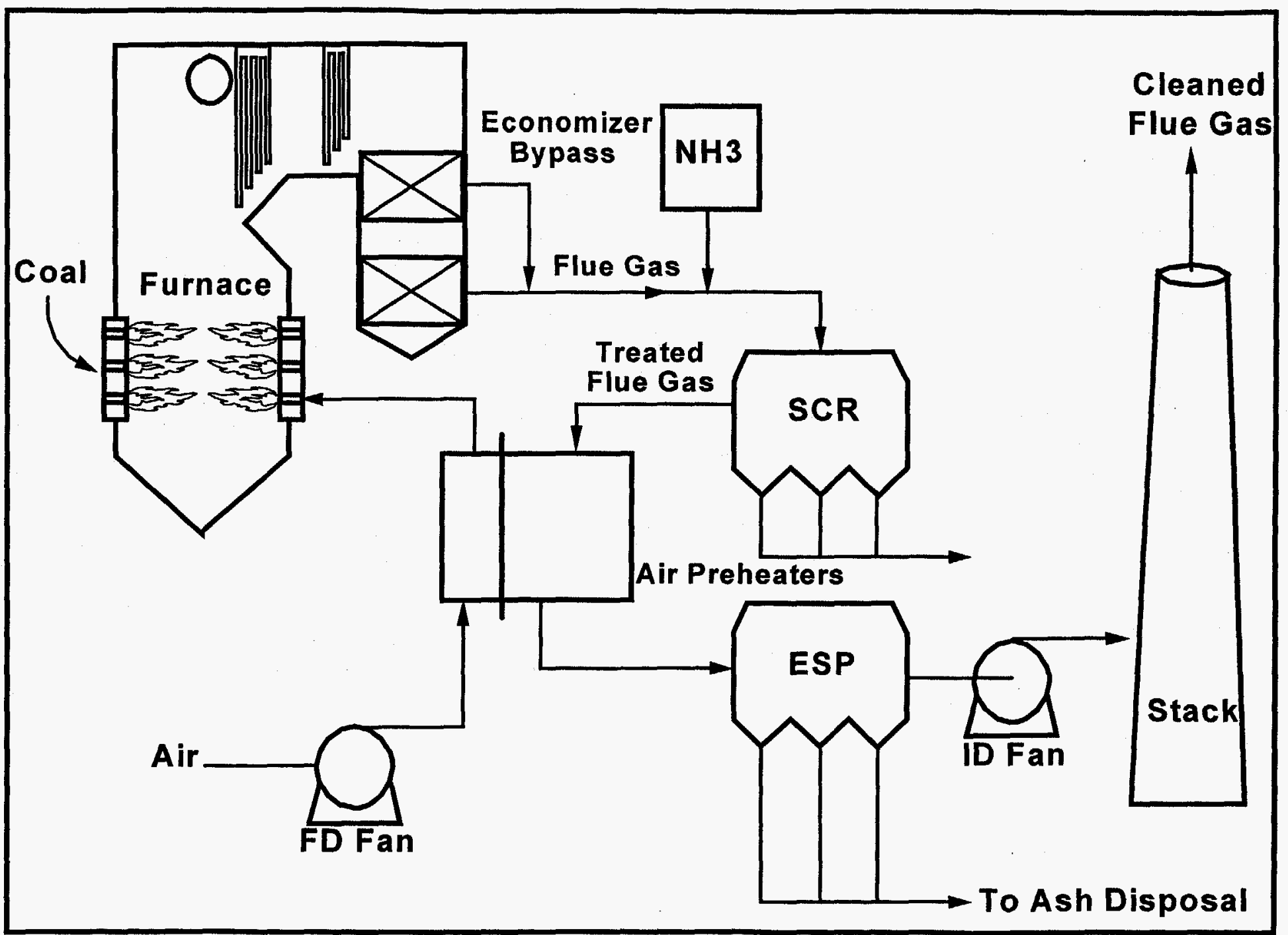

Figure 1. Flow Diagram of Typical SCR Installation 
The SCR technology is in commercial use in Japan and western Europe on gas-, oil-, and on lowsulfur, coal-fired power plants. The first utility applications of SCR catalyst technology started in Japan in 1977 for oil- and gas-fired boilers and subsequently in 1979 for coal-fired boilers. As of 1986, ninety utility boilers in Japan had been equipped with SCR catalyst technology including twenty-two coal-fired boilers. These coal-fired boilers represent a combined capacity in excess of $6500 \mathrm{MWe}$ and are typically fired with a low-ash, low-sulfur coal.

In addition to Japanese experience, several countries in western Europe (most notably Germany and Austria) have passed stringent $\mathrm{NO}_{\mathrm{x}}$ emission regulations that have all but mandated the installation of SCR. Prior to commercial SCR installations in Germany, utility companies demonstrated several types of SCR facilities in prototype demonstration programs similar to this ICCT project. Over $50 \mathrm{SCR}$ pilot plants were built and operated in western Europe. These pilot plants ranged from 19 to 6200 SCFM and provided the data base that led to commercialization of the SCR technology in western Europe.

Previously completed U. S. work with the SCR process on utility boilers consists of three projects which were carried out in the late 1970 s and early 1980s. One of these was carried out on a natural gas fired boiler by Southern California Edison. Another project consisted of a pilot test conducted for the EPA at Georgia Power's Plant Mitchell. This pilot plant treated a 1000 ACFM ( $0.5 \mathrm{MWe})$ slip stream of flue gas resulting from the combustion of low- to mediumsulfur coal. A third pilot-scale project, carried out at the Public Service Company of Colorado's Arapaho Station treated a 5000 ACFM (2.5 MWe) slip stream of flue gas resulting from the combustion of U. S. low-sulfur coal.

Although SCR is widely practiced in Japan and Europe, there are numerous technical uncertainties associated with applying SCR to U. S. coals. These uncertainties include:

(1) potential catalyst deactivation due to poisoning by trace metal species present in U. S. coals that are not present in other fuels.

(2) performance of the technology and effects on the balance-of-plant equipment in the presence of high amounts of $\mathrm{SO}_{2}$ and $\mathrm{SO}_{3}$.

(3) performance of a wide variety of SCR catalyst compositions, geometries and methods of manufacture under typical high-sulfur coal-fired utility operating conditions. 
These uncertainties are being explored by operating a series of small-scale SCR reactors and simultaneously exposing different SCR catalysts to flue gas derived from the combustion of high sulfur U. S. coal.

The first uncertainty above is being handled by evaluating SCR catalyst performance for two years under realistic operating conditions found in U. S. pulverized coal utility boilers. The deactivation rates for the catalysts exposed to flue gas from high sulfur U. S. coal will be documented to determine accurate catalyst life, and thus, accurate process economics.

The second uncertainty above is being explored by performing parametric testing and through the installation/operation of air preheaters downstream of the larger reactors. During parametric testing, operating conditions are adjusted above and below design values to observe deNO performance and ammonia slip as functions of the change in operating conditions. Air preheater performance is observed to evaluate effects from SCR operation upon heat transfer, and therefore, upon boiler efficiency.

The third uncertainty is being handled by using honeycomb- and plate-type SCR catalysts from U. S., Japan and Europe of various commercial composition. Results from the tests with these catalysts expands our knowledge of performance on a variety of SCR catalysts under U. S. utility operating conditions with high-sulfur coal.

The intent of this project is to demonstrate commercial catalyst performance, proper operating conditions, and catalyst life for the SCR process. This project is also demonstrating the technical and economic viability of $\mathrm{SCR}$ while reducing $\mathrm{NO}_{\mathrm{X}}$ emissions by at least $80 \%$.

The project is being conducted at Gulf Power Company's Plant Crist Unit 5, a commercially operating $75 \mathrm{MW}$ unit, located in Pensacola, Florida, on U. S. coals with a sulfur content near $3.0 \%$. Unit 5 is a tangentially-fired, dry bottom boiler, with hot and cold side ESPs for particulate control. The SCR process used in this demonstration is designed to treat a slip-stream of flue gas and features multiple reactors installed in parallel. With all reactors in operation, the maximum amount of combustion flue gas that can be treated is 17,400 standard cubic feet per minute (scfm) which is roughly equivalent to $8.7 \mathrm{MWe}$.

The SCS facility is a slip-stream SCR test facility consisting of three $2.5 \mathrm{MWe}$ (5000SCFM) SCR reactors and six $0.20 \mathrm{MWe}(400 \mathrm{SCFM})$ reactors that operate in parallel for side-by-side comparisons of commercially available SCR catalyst technologies obtained from vendors 
throughout the world. Figure 2 presents a simplified process flow diagram for the proposed facility. The large (2.5 MWe) SCR reactors contain commercially available SCR catalysts as offered by SCR catalyst suppliers. These reactors were coupled with small-scale air preheaters to evaluate the long-term effects of SCR reaction chemistry on air preheater deposit formation and the deposits' effects on air preheater. The small reactors are used to test additional commercially available catalysts. This demonstration facility size is adequate to develop performance data to evaluate SCR capabilities and costs that are applicable to boilers using high-sulfur U. S. coals.

The demonstration project is organized into three phases: (1) Phase I - Permitting, Environmental Monitoring Plan and Preliminary Engineering; (2) Phase II - Detail Design Engineering and Construction; and (3) Phase III - Operation, Testing, Disposition, and Final Report. The cooperative agreement was signed June 14, 1990, and the project completion date is now projected to be at the end 1995 . The original total estimated project costs were $\$ 15.6$ million but project growth increased the expected total cost to $\$ 23$ million. The co-funders are SCS (\$10 million), DOE (\$9.4 million), EPRI (\$2.9 million) and Ontario Hydro ( $\$ 0.75$ million). 


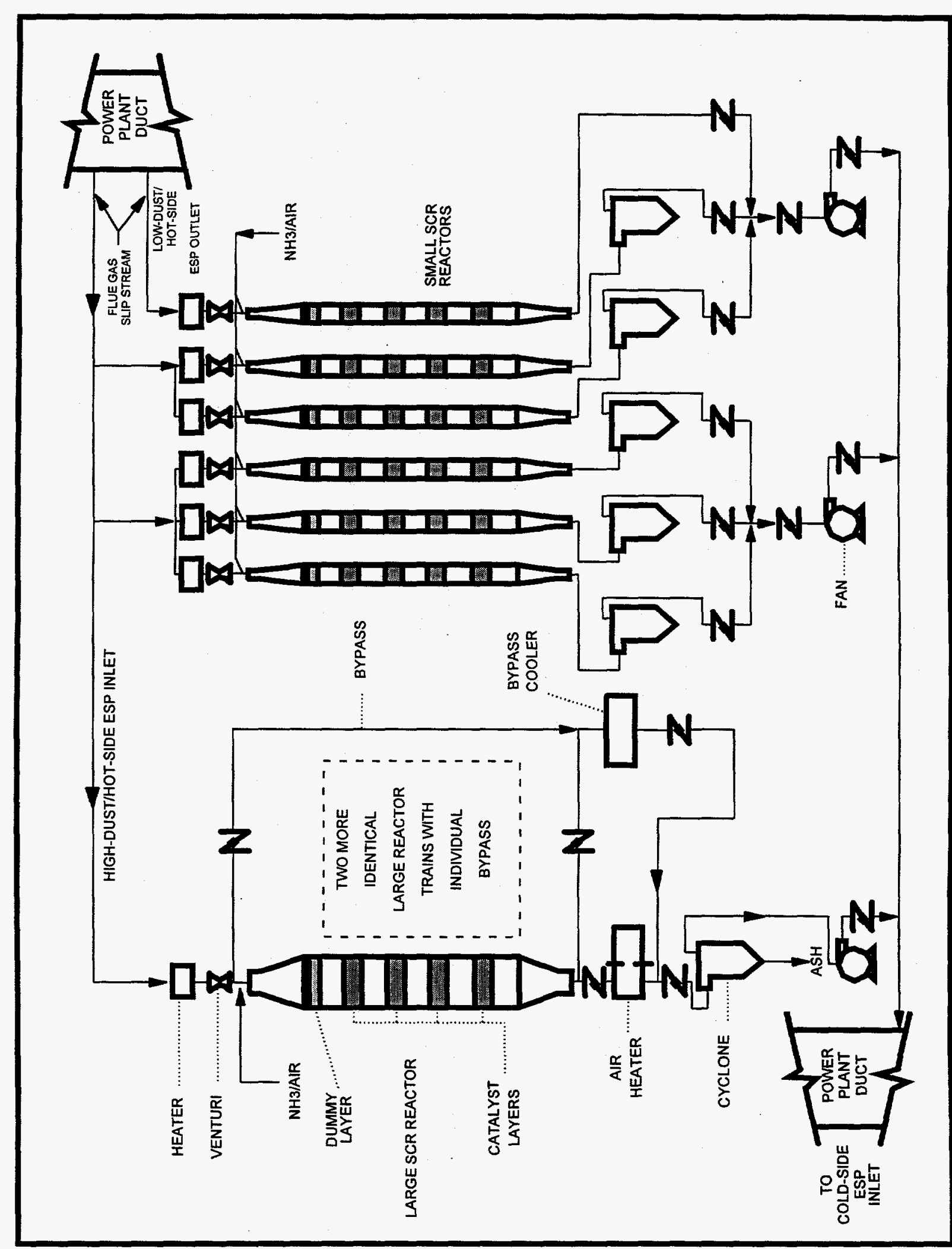

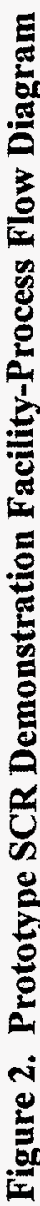




\section{Section 3 \\ PROJECT DESCRIPTION}

Within the three phases of the project, the following tasks are to be conducted to effectively demonstrate the SCR process:

Phase I - Permitting, Environmental Monitoring Plan and Preliminary Engineering

Task 1.1.1 - Prototype Plant Permitting Activities

Task 1.1.2 - Develop Environmental Monitoring Program

Task 1.1.3 - Preliminary Engineering

Task 1.1.4 - Engineering and Construction Contracts Scope Development

Task 1.1.5 - Project Management and Reporting

Phase II - Detail Design Engineering and Construction

Task 1.2.1 - Detailed Design Engineering

Task 1.2.2 - Construction

Task 1.2.3 - Operation Staff Training

Task 1.2.4 - Planning for Detailed Testing

Task 1.2.5 - Start-Up/Shakedown

Task 1.2.6 - Project Management and Reporting

Phase III - Operations, Testing, Disposition and Final Report

Task 1.3.1 - SCR Demonstration Facility Operations and Maintenance

Task 1.3.2 - Process Evaluation

Task 1.3.3 - Environmental Data Management and Reporting

Task 1.3.4 - Economic Evaluation

Task 1.3.5 - Dismantling/Disposition

Task 1.3.6 - Project Management and Reporting 
Section 4

PROJECT STATUS

Progress during October - December, 1993, is summarized below for each of the on-going tasks in the Scope of Work.

PHASE III - OPERATIONS, TESTING, DISPOSITION, AND FINAL REPORT

\section{Task 1.3.1 - SCR Demonstration Facility Operations and Maintenance}

The catalyst vendors, assigned reactors, and the total number of operating hours with exposure to flue gas for each reactor by the end of the quarter are as follows:

$\begin{array}{lcc}\text { Catalyst supplier } & \text { Reactor designation } & \text { Operating hours } \\ \text { W. R. Grace } & \text { A (large) } & 2666 \\ \text { Nippon Shokubai } & \text { B (large) } & 3568 \\ \text { Siemens } & \text { C (large) } & 3517 \\ \text { W. R. Grace } & \text { D (small) } & 1891 \\ \text { Cormetech } & \text { E (small) } & 1891 \\ \text { Haldor Topsoe } & \text { F (small) } & 1891 \\ \text { Hitachi Zosen } & \text { G (small) } & 408 \\ \text { Engelhard } & \text { H (small) } & 917 \\ \text { Engelhard } & \text { J (small) } & 511\end{array}$

The preliminary parametric test sequences for the three large reactors $(\mathrm{A}-\mathrm{C})$ were completed the previous quarter. During this fourth quarter of 1993, the large reactors were operated in longterm base operating conditions, i.e. at an ammonia/ $\mathrm{NO}_{\mathrm{x}}$ ratio near 0.83 for $80 \% \mathrm{NO}_{\mathrm{x}}$ removal. The parametric tests for Reactors D - F were completed after an operational shakedown period consisting of recalibration of the venturi and ammonia mass flow controllers on each of the reactors, as well as a check-out of the gas analysis equipment. Although parametric testing was initiated, testing was interrupted and not completed on Reactors G - J. The reasons for this incomplete testing are discussed later in this section.

The test facility experienced several outages during October. Two outages were a result of the Unit 5 boiler being forced off-line, thus causing a test facility outage. The test facility operators used these times to clean fans and inspect the cyclones for plugging. A scheduled test facility 
outage occurred over a Saturday to replace the service water bypass valve with an upgraded version. Also, failure of one of the control system's analog input cards forced the small reactors to be taken off-line part of a day while manual overrides kept the large reactors on-line until the card was replaced.

There was a planned outage during the first week of November, during which the first catalyst samples were retrieved from the three large reactors and sent to the catalyst suppliers for laboratory testing. Upon inspection, the top catalyst bed on Reactor $\mathrm{C}$ was found to be damaged by the sootblower rake twisting in the reactor and physically striking the catalyst modules. At the end of December during the next outage for catalyst sampling, the catalyst in reactor $C$ which had been previously damaged by physical contact with the sootblower, was replaced. (Although this catalyst had been physically damaged, there had been no previous indication operationally $\left[\mathrm{NO}_{\mathrm{x}}\right.$ removal and pressure drop] that this damage was happening. Thus, although damaged, the catalyst was still yielding excellent $\mathrm{NO}_{\mathrm{x}}$ reduction performance.) Since the catalyst module for each layer in Reactor $C$ consisted of two levels of catalyst baskets, the new replacement catalyst baskets were loaded into the bottom of the first bed. The original catalyst in the lower half of the first catalyst bed, which had not been damaged, was moved to the top half of the first bed. The reactor sootblowers were inspected and repaired as needed, with most having their rake covers trimmed for clearance and all fitted with an external anti-rotation device to prevent a similar occurrence as previously experienced on Reactor $\mathrm{C}$.

During the early November catalyst sampling on the three large reactors, the dummy bed on Reactor A was discovered to be heavily eroded, and plans were made to replace the dummy bed. This dummy bed replacement was accomplished in late December. The dummy bed in Reactor D was also replaced since it was the same material as that originally in Reactor A. Otherwise, the dummy beds and catalyst baskets had little apparent damage or erosion and were relatively clean regarding fouling from ash.

Also in November, the test facility experienced a few outage days due to Unit 5 tube failures and loss of power from the switchyard due to a transformer failure on Unit 6.

During an outage over the Thanksgiving holiday, the plate catalyst in Reactor $G$ was inspected due to a large increase in pressure drop noticed prior to the outage. About half the catalyst elements were found to be damaged, collapsed upon itself. Based upon inspection, the vertically downward sootblowing with air was thought to be the cause of the damage. All but two of the nine reactor catalysts are sampled directly from the actual catalyst beds. However in Reactors F 
and $\mathrm{G}$, the catalyst is a monolithic plate structure which prohibits samples being pulled directly from the catalyst bed. In these two reactors, catalyst coupons were mounted above each catalyst bed for catalyst sampling purposes (also at the outlet of the last bed in Reactor F). It appears that the air sootblowing procedures destroyed the coupons, and in Reactor G, the coupons subsequently fell down and damaged the main catalyst layers. The catalyst supplier provided replacement catalyst elements for installation in the first quarter of 1994. Per the vendor's advice, this catalytic reactor will be operated in the future without sootblowing. Operation of this reactor ceased until the catalyst is replaced early in 1994.

During the holidays at the end of December, there was a planned outage for catalyst sampling and facility modifications. Reactors A - F were inspected and catalyst samples taken and sent to the suppliers for laboratory analysis. The only catalyst sampling coupons present for the December sampling in Reactor $F$ were those at the reactor exit for Reactor F, and there were no coupons for Reactor G. As just noted above, the catalyst sample coupons for Reactors F and $G$ were destroyed due to air sootblowing procedures. Replacement coupons have been supplied and were installed as soon as received.

Also during the December planned outage, valves and test ports, not insulated originally, were insulated to reduce heat losses. Additional insulation projects are being planned in the future to assist operations in maintaining desired temperatures. The control system was also reconfigured for calibration equation corrections on the venturis and ammonia flow controllers (see the later discussions on gas sampling and ammonia-to- $\mathrm{NO}_{\mathrm{x}}$ ratios.)

As with the previous quarter, Southern Research Institute (SRI) continued this quarter to maintain a staff of six people, supplementing their regular staff of three people with two additional testing crew and an additional analytical chemist. This doubling of staff was required to complete the preliminary parametric testing on all reactors before the end of December 1993.

Laboratory analysis was begun by the catalyst suppliers on the catalyst samples taken after one quarter of operation on the three large reactors. Initial results indicate little or no loss in overall kinetic activity and little change in other critical properties. Upon completion of the initial parametric testing in early December, base-line ammonia slip measurements were repeated. These tests were completed during December and the results indicated all catalysts were performing well with less than $2 \mathrm{ppm}$ slip under base-line conditions, and in many cases the measured slip was below the $1 \mathrm{ppm}$ detection limit. 
Several other major experiences encountered during operation are highlighted below.

- Dilution/Extraction Gas Sampling/Monitoring System

The SCR test facility uses a dilution/extraction sampling system from Lear Seigler Measurement Controls Corporation (LSMCC, now Monitor Labs). The system consists of thirteen dilution/extraction probes for the measurement of $\mathrm{NO}_{x}, \mathrm{SO}_{2}, \mathrm{CO}_{2}$, and $\mathrm{CO}$. There are twentysix Yokagawa in-situ probes for the measurement of oxygen. Using dry air as a dilution medium, normal dilution ratios range from 30:1 to $250: 1$. $\mathrm{NO}_{\mathrm{x}}$ analysis is performed using an LSMCC ML8840 chemiluminescence $\mathrm{NO}_{\mathrm{x}}$ analyzer with a detection limit of $2 \mathrm{ppb}$ resulting in a flue gas detection limit of approximately $0.25 \mathrm{ppm}$. CO is measured using a LSMCC model ML8830 infrared CO analyzer with a detection limit of $0.1 \mathrm{ppm}$ resulting in a flue gas detection limit of approximately $3 \mathrm{ppm}$. $\mathrm{CO}_{2}$ is measured using a Siemens Ultimat 5E non-dispersive infrared $\mathrm{CO}_{2}$ analyzer. $\mathrm{SO}_{2}$ is measured using a LSMCC model ML8850 fluorescence $\mathrm{SO}_{2}$ analyzer with a detection limit of $1 \mathrm{ppb}$ resulting in a flue gas detection limit of $0.1 \mathrm{ppm}$. Oxygen is measured using in-situ zirconium oxide cell technology.

The issues reported for the previous quarter continued to be addressed during this quarter. These problems included coordinating the time-shared analyzers and communicating with the test facility's data collection system. For the nine reactors, there are three $\mathrm{NO}_{\mathrm{x}}$ analyzers for the reactor outlet measurements. Each of these analyzers operate on a time-shared basis serving three specific reactors. These systems use a complex system of pumps and valves to direct the sample that is continuously extracted to the analyzer. Problems with erroneous data being transmitted for the two points which are supposedly holding their previous values while the third reactor sampling point is active were resolved.

The gas analyzer system has a dedicated programmable controller that collects the data from all the analyzers and then sends them to the test facility's control and data collection system. Because these are different systems, the communication protocol had to be worked out during start-up and this effort was completed during this last quarter of 1993.

In addition to the above problems, significant dilution effects due to air in-leakage into the reactor were also creating apparent data anomalies. The $\mathrm{NO}_{\mathrm{x}}$ concentration inputs for automatic ammonia injection were taken from the inlet ductwork to the pilot plant, rather than from the ammonia injection point. Therefore, air in-leakage after the sample point decreased the $\mathrm{NO}_{\mathbf{x}}$ concentration at the ammonia injection point. This skewed the calculation for ammonia injection 
rate and resulted in a higher than expected ammonia-to- $\mathrm{NO}_{\mathrm{x}}$ ratio. Of course, the ammonia injection rate can easily be corrected by material balance to compensate for oxygen in-leakage. This, however, links a large number of continuous measurements to the calculation, resulting in frequent errors when one of the measurement points is not operating correctly. To avoid similar problems in the future, $\mathrm{NO}_{\mathrm{x}}$ readings should be taken close to the ammonia injection point, rather than upstream of potential in-leakage sources.

Problems previously experienced with $\mathrm{NO}_{\mathrm{x}}$ measurements in the presence of ammonia, apparently with catalytic reactions proceeding in the sampling system, thus reducing $\mathrm{NO}_{\mathrm{x}}$ before the sample reaches the analyzers, continued. There has been a series of traps and filters previously installed in the sample line to capture the ash, water vapor and acid condensate in order to improve the accuracy of the analyzer system. The original dilution probe, made of Inconel, for measuring $\mathrm{NO}_{x}$ at intermediate levels in the reactors appeared to produce up to $30 \%$ $\mathrm{NO}_{\mathrm{x}}$ reduction in the presence of ammonia, thus giving low $\mathrm{NO}_{\mathrm{x}}$ readings at the analyzer. In December 1993, after modifying the probe with $316 \mathrm{SS}$, the probe was re-tested with and without ceramic probe tips. The results were still the same, with or without the ceramic probe tips, i.e., about $30 \% \mathrm{NO}_{\mathrm{x}}$ reduction across the probe. Work continued to resolve this issue with plans formulated to evaluate a glass-lined tip early in 1994.

The above issues were the reasons there were rather limited long-term operating data during this period.

\section{- Ammonia Injection Flow Control}

Precision mass flow control valves supplied by Sierra Instrumentation were installed to control the ammonia vapor flow rates for injection into the reactors. These controllers were affected by liquid in the flow stream, pressure variations, trash in the line, and also the orientation of the controller itself. These controllers were calibrated on nitrogen and scaled to read ammonia flow. Although initial results indicated accurate flow control, subsequent measurements indicated that actual ammonia flow was 10 to 25 percent higher than the controllers were indicating. Action taken to correct this situation included installing coalescent filters on the ammonia supply lines to each control valve, reorienting the controllers, replacing the ammonia header pressure regulator, cleaning each controller, and recalibrating and verifying with other instruments.

After the above changes, the results for the controllers on the large reactors were still unacceptable. One of the original ammonia flow controllers, was replaced with another vendor's 
controller (Brooks) for a trial period of two months. The evaluation was concluded in December and based on the better performance of the Brooks' equipment, the decision was made to replace the original ammonia flow controllers for the large reactors.

\section{- Low Dust Reactor Fouling}

As reported in the previous progress report, the low-dust reactor, Reactor J, experienced severe plugging of the first catalyst layer after only a few hours of operation during its first start-up after catalyst loading. While the large reactor bypass lines may be used to flush any ash accumulations associated with the main extraction scoop, the low dust reactor ductwork was not provided with any bypass capability. Also, the isolation damper for that line is approximately $100^{\prime}$ downstream of the scoop allowing a deadleg for sulfate formation when the reactor is offline. So during start-up an unusually large amount of solid material may have been introduced to the low-dust reactor. The first layer catalyst element was returned to the catalyst vendor for examination and a study undertaken to evaluate solutions to prevent recurrence of this problem. The resulting design changes previously approved to prevent recurrence of the plugging problem on the low dust reactor included the following: the reactor isolation and purge dampers should be relocated to minimize the deadleg; and the reactor heater capacity would be increased and the heater moved to just downstream of the isolation damper to raise the minimum gas temperature throughout the entire length of ductwork between the scoop and reactor inlet. During the fourth quarter of 1993, these changes were implemented at the test facility.

However, prior to restarting Reactor J, Engelhard cited commercial reasons for withdrawing from the project. Thus, operation of both Reactors $\mathrm{H}$ and $\mathrm{J}$ were ceased temporarily because of this decision. Solicitation, evaluation, and selection of catalyst replacements are to be performed during the next reporting period. 
- Reactor and Air Preheater Sootblowing

During normal operation, reactor and air heater pressure drops do slowly increase, but these were usually controlled by sootblowing. The large reactors are equipped with retracting lances with a perpendicular array of nozzles mounted that blow steam across the catalyst as the lance traverses across the reactor. The steam sootblowers on the air preheaters are stationary and use steam. Much work went into eliminating the condensate from the sootblowing steam supply piping before the sootblowers extend into the reactors, including an extra steam isolation valve on each sootblower, using a process steam condensate trap on each reactors steam supply header, and adding warm-up vents to assure the piping is hot enough to prevent condensation. The small reactors are blown by air lance inserted through a ball valve installed above each basket layer. The schedules and procedures for sootblowing of the reactors and air preheaters are shown below. As noted previously, sootblowing on Reactor $G$ will cease when operation resumes with a replacement catalyst.

\section{Sootblowing}

Schedules:

$$
\begin{aligned}
& \text { Large Reactors - every } 8 \text { hours } \\
& \text { Small Reactors - every } 8 \text { or } 12 \text { hours } \\
& \text { Air Preheaters - every } 4 \text { hours }
\end{aligned}
$$

Procedures:

- Warm-up lines by venting the top of verticals

- Condensate drains under each vertical and air preheater

- Monitoring pressure drops-before/after

\section{- Bypass Heat Exchangers}

The bypass heat exchangers, which were included for use during the parametric testing on the large reactors to minimize effects of high ammonia slip upon the long-term evaluation of the air preheaters, were easily plugged by ash and sulfate deposits during start-up. Cleaning with either air or water has not been a satisfactory solution. Other means to cool the flue gas while bypassing the air preheaters were evaluated during this reporting period without satisfactory results (based on expected performance or costs). The decision was made to continue to allow flue gas to pass through the air preheaters during parametric testing, thus always bypassing these bypass heat exchangers. The parametric tests are for brief periods of time and the higher ammonia $/ \mathrm{NO}_{\mathrm{x}}$ ratios $(>0.80)$ are only a portion of these tests. Therefore, the total time 
excursions at relatively high ammonia slip levels should minimally effect the long-term evaluation of the air preheaters.

- Measurement Accuracy/Repeatability

The majority of manual measurements are made using triplicate samples. This insures the quality of the data and helps to remove operating variability from the results. Since triplicate measurements usually require several hours to complete, they also help to evaluate and insure that steady-state operation has been achieved for the particular test conditions. Each of the triplicate samples are analyzed in duplicate in the laboratory. Thus, six values are acquired for each average reported measured value. Detection limits for ammonia slip measurements are normally approximately $1 \mathrm{ppm}$ with analytical repeatability to within $0.1 \mathrm{ppm}$. Intermediate ammonia detection limits are somewhat higher, namely 1 to $2 \mathrm{ppm}$ with analytical repeatability to within $1 \mathrm{ppm}$. $\mathrm{SO}_{2}$ measurements normally have detection limits of $5 \mathrm{ppm}$ with analytical repeatability to within $1 \%$ of the measured value. $\mathrm{SO}_{3}$ detection limits are normally $0.4 \mathrm{ppm}$ with an analytical repeatability to within $0.4 \%$ of the measured value.

\section{Task 1.3.2 - Process Evaluation}

- Coal Chemistry

Coal samples were analyzed monthly for major components and certain trace elements. The monthly results and quarterly averages for October through December are shown in Table 1. Also given for comparison are the results for the previous months of July - September, yearly averages, and project-to-date averages.

\section{- Flue Gas Composition}

Several flue gas constituents are measured continuously by the gas analyzer system (described previously) at the SCR test facility inlet. Table 2 shows the constituent concentrations in terms of average values, normal high values, and normal low values over the reporting period. These quarterly values were determined using daily averages, daily highs, and daily lows during periods that the host boiler was on-line (operating at greater than $40 \mathrm{MWe}$ ). 
Table 1: Plant Crist Unit 5 Coal Analyses - 1993 Monthly, As-Burned Composites Alabama Power Company Results, Dry Basis

\begin{tabular}{|c|c|c|c|c|c|c|c|c|c|c|c|c|}
\hline SCS ID No. & & & 93-354 & $93-386$ & $93-415$ & $93-469$ & 93-649 & $93-614$ & 1993 & "Total & "Total & 4th Qtr.'93 \\
\hline Test & Method & Units & July & August & September & October & November & December & Average & Average & Std. Dev. & Average \\
\hline Moisture, Total & ASTMD 3302 & $\%$ by Wt. & 11.04 & 10.71 & 9.45 & 10.23 & 9.98 & 9.95 & 10.45 & 10.45 & 0.74 & 10.05 \\
\hline Ash & ASTMD 3180 & \% by wh. & 10.09 & 9.36 & 10.55 & 10.23 & 9.87 & 9.01 & 9.62 & 9.62 & 0.56 & 9.70 \\
\hline Gross Calorific Value & ASTMD 3180 & Btunb & 13113 & 13270 & 13095 & 13139 & 13251 & 13387 & 13231 & 13231 & 97 & 13259 \\
\hline Sulfur, Total & ASTM D 3180 & $\%$ by Wt. & 3.02 & 2.86 & 2.94 & 2.51 & 2.28 & 2.62 & 2.79 & 2.79 & 0.24 & 2.47 \\
\hline Sulfur, $16 / M M B$ tu & ASTMD 3180 & Ib/MiMBtu & 2.30 & 2.16 & 2.25 & 1.91 & 1.72 & 1.96 & 2.11 & 2.11 & 0.19 & 1.86 \\
\hline Carbon & ASTMD 3180 & $\%$ by $\mathrm{Wt}$. & 74.23 & 74.77 & 73.95 & 73.74 & 74.62 & 75.51 & 74.67 & 74.67 & 0.54 & 74.62 \\
\hline Hydrogen & ASTMD 3180 & \%byw. & 4.98 & 5.06 & 4.96 & 5.00 & 4.95 & 5.04 & 5.03 & 5.03 & 0.06 & 5.00 \\
\hline Nitrogen & ASTMD 3180 & $\%$ by Wt. & 1.55 & 1.57 & 1.57 & 1.57 & 1.63 & 1.66 & 1.58 & 1.58 & 0.04 & 1.62 \\
\hline Oxygen & ASTMD 3180 & \% by Wt. & 6.13 & 6.38 & 6.03 & 6.95 & 6.65 & 6.16 & 6.31 & 6.31 & 0.34 & 6.59 \\
\hline Carbon, Fixed & ASTMD 3180 & \% by W. & 50.13 & 52.43 & 51.44 & 50.53 & 54.43 & 52.03 & 51.61 & 51.61 & 1.19 & 52.33 \\
\hline Volatile Matter & ASTMD 3180 & \% by Wt. & 39.78 & 38.21 & 38.01 & 39.24 & 35.70 & 38.96 & 38.77 & 38.77 & 1.25 & 37.97 \\
\hline Aluminum & ASTMD 3682 & \% by wh. & 0.97 & 1.07 & 1.24 & 1.23 & 1.18 & 1.02 & 1.09 & 1.09 & 0.12 & 1.14 \\
\hline Antimony & ASTM D 3683 & $\mathrm{mg} / \mathrm{kg}$ & $<1$ & $<1$ & 7 & $<1$ & 2 & 1 & 1 & $<1$ & -- & $\frac{1.17}{1}$ \\
\hline Arsenic & Slurry/GFAAS & $\mathrm{mg} / \mathrm{kg}$ & 2.3 & 2.9 & 7.6 & 5.3 & 7.1 & 4.1 & 3.4 & 3.4 & 2.6 & 5.5 \\
\hline Barium & ASTMD 3683 & $\mathrm{mg} / \mathrm{kg}$ & 44 & 36 & 72 & 74 & 96 & 55 & 53 & 53 & 21 & 75 \\
\hline Beryllium & ASTMD 3683 & $m g / k g$ & 3 & 2 & 3 & 3 & 3 & 3 & 3 & 3 & 0 & 3 \\
\hline Cadmium & ASTM D 3683 & $\mathrm{mg} / \mathrm{kg}$ & $<1$ & $<1$ & $<1$ & $<1$ & $<1$ & $<1$ & $<1$ & $<1$ & - & $<1$ \\
\hline Calcium & ASTMD 3682 & \%by W. & 0.27 & 0.28 & 0.26 & 0.20 & 0.24 & 0.27 & 0.26 & 0.26 & 0.03 & 0.24 \\
\hline Chlorine & ASTMD 4208 & $m g / k g$ & 1341 & 1429 & 1716 & 812 & 1210 & 1395 & 1294 & 1294 & 453 & 1139 \\
\hline Chromium & ASTMD 3683 & $\mathrm{mg} / \mathrm{kg}$ & 18 & 16 & 23 & 21 & 19 & 19 & 19 & 19 & 3 & 20 \\
\hline Cobalt & ASTM D 3683 & $\mathrm{mg} / \mathrm{kg}$ & 7 & 5 & 9 & 9 & 10 & 9 & 8 & 8 & 2 & 9 \\
\hline Copper & ASTMD 3683 & $\mathrm{mg} / \mathrm{kg}$ & 8 & 7 & 12 & 13 & 11 & 13 & 9 & 9 & 3 & 12 \\
\hline Fluorine & ASTMD 3761 & $\mathrm{mg} / \mathrm{kg}$ & 24 & 92 & 90 & 47 & 58 & 66 & 50 & 50 & 27 & 57 \\
\hline Iron & ASTM D 3682 & $\%$ by Wt. & 1.13 & 0.95 & 1.24 & 1.11 & 1.20 & 1.15 & 1.08 & 1.08 & 0.14 & 1.15 \\
\hline Lead & ASTIMD 3683 & $\mathrm{mg} / \mathrm{kg}$ & 7 & 15 & 9 & 7 & 8 & 10 & 12 & 12 & 6 & 8 \\
\hline Lithium & ASTMD 3683 & $\mathrm{mg} / \mathrm{kg}$ & 5 & 5 & 7 & 11 & 14 & 6 & 7 & 7 & 3 & 10 \\
\hline Magnesium & ASTMD 3682 & $\%$ by Wt. & 0.05 & 0.06 & 0.05 & 0.02 & 0.06 & 0.06 & 0.05 & 0.05 & 0.01 & 0.05 \\
\hline Manganese & ASTMD 3682 & $\mathrm{mg} / \mathrm{kg}$ & 22 & 21 & 28 & 24 & 23 & 22 & 23 & 23 & 2 & 23 \\
\hline Mercury & ASTMD $36 \overline{84}$ & $\mathrm{mg} / \mathrm{kg}$ & $<0.02$ & 0.10 & 0.14 & 0.17 & 0.15 & 0.15 & 0.09 & $\overline{0.09}$ & 0.06 & 0.16 \\
\hline Molybdenum & ASTMD $368 \overline{3}$ & $\mathrm{mg} / \mathrm{kg}$ & 11 & 13 & 16 & 5 & $<1$ & 6 & 8 & 8 & 4 & 4 \\
\hline Nickel & ASTMD 3683 & $\mathrm{mg} / \mathrm{kg}$ & 14 & 11 & 16 & 15 & 18 & 17 & 15 & 15 & 2 & 17 \\
\hline Phosphorus & ASTMD 3682 & \% by Wt. & 0.01 & 0.05 & 0.12 & 0.04 & 0.04 & 0.02 & 0.04 & 0.04 & 0.03 & 0.03 \\
\hline Potassium & ASTMD 3682 & $\%$ by Wt. & 0.18 & 0.31 & 0.25 & 0.17 & 0.32 & 0.16 & 0.23 & 0.23 & 0.05 & 0.22 \\
\hline Selenium & Slurry/GFAAS & mg/kg & $<2$ & 2 & 2 & 2 & $<2$ & $<2$ & $<2$ & $<2$ & $\ldots$ & $<2$ \\
\hline Silica & ASTMD 3682 & $\%$ by $W t$. & 2.42 & 2.15 & 2.61 & 2.45 & 2.63 & 2.01 & $2.3 \overline{3}$ & 2.33 & 0.20 & 2.36 \\
\hline Sodium & ASTMD 3682 & \% by W. & 0.11 & 0.05 & 0.04 & 0.05 & 0.06 & 0.06 & 0.06 & 0.06 & 0.02 & 0.06 \\
\hline Titanium & ASTMD 3682 & \% by WE. & 0.06 & 0.07 & 0.06 & 0.05 & 0.07 & 0.06 & 0.06 & 0.06 & 0.01 & 0.06 \\
\hline Vanadium & ASTMD 3683 & $\mathrm{mg} / \mathrm{kg}$ & 66 & 38 & 56 & 45 & 40 & 44 & 49 & 49 & 8 & 43 \\
\hline Zinc & ASTMD 3683 & $\mathrm{mg} / \mathrm{kg}$ & 32 & 28 & 29 & 23 & 25 & 43 & 33 & 33 & 7 & 30 \\
\hline
\end{tabular}

*Total Includes Average and Standard Deviation from March '93 through Latest Month Shown

$<$ Less Than Detection Limit. 


\section{TABLE 2. TEST FACILITY GAS CONCENTRATIONS}

Oct.-Dec. '93

$\begin{array}{llll}\text { Constituent } & \text { Average } & \text { High } & \text { Low } \\ \text { Unit \#5 Load (MW) } & 62 & 79 & 43 \\ \text { Inlet } \mathrm{NO}_{\mathrm{X}}(\mathrm{ppm}) & 316 & 367^{\circ} & 268 \\ \text { Inlet } \mathrm{O}_{2}(\%) & 5.6 & 7.1 & 2.5 \\ \text { Inlet } \mathrm{CO}_{2}(\%) & 14.4 & 16.5 & 11.9 \\ \text { Inlet } \mathrm{CO}(\mathrm{ppm}) & 24 & 165 & 2 \\ \text { Inlet } \mathrm{SO}_{2}(\mathrm{ppm}) & 1490 & 1680 & 1275\end{array}$

- Mass Concentration and Particle Size Distribution

The mass concentration and particle size distribution measurements to confirm all reactors were receiving fly ash similar in concentration and particle size to that of the fly ash in the main plant ductwork were reported in the previous quarterly progress report. Please see the progress report for April - September 1993 for this information.

- Fly Ash Chemistry and Resisitivity

Ash mineral analyses and fly ash resistivity data were reported previously in the April September, 1993 progress report.

- Ammonia/ $/ \mathrm{NO}_{\mathrm{X}}$ Ratio

The ammonia-to- $\mathrm{NO}_{\mathrm{x}}$ ratio is normally maintained to give approximately $80 \%$ reduction in $\mathrm{NO}_{\mathrm{x}}$ across the reactors. This gives a theoretical required ammonia-to- $\mathrm{NO}_{\mathrm{x}}$ ratio of roughly 0.83 assuming that the flue gas $\mathrm{NO}_{\mathrm{x}}$ concentration consists of $5 \% \mathrm{NO}_{2}$. However, oxygen inleakage can cause an increase in ammonia-to- $\mathrm{NO}_{\mathrm{x}}$ ratio if the $\mathrm{NO}_{\mathrm{x}}$ values are measured upstream of the flue gas metering device. This is the case in the SCR reactors. As a result, an ammonia-to- $\mathrm{NO}_{\mathrm{x}}$ ratio of 0.83 gives an effective ammonia-to- $\mathrm{NO}_{\mathrm{x}}$ ratio of approximately 0.88 in the SCR reactors. Consequently, the ammonia to $\mathrm{NO}_{\mathrm{x}}$ ratio is normally set at 0.74 to 0.76 , resulting in an effective ammonia-to- $\mathrm{NO}_{\mathrm{x}}$ ratio of about 0.81 , giving a $\mathrm{NO}_{\mathrm{x}}$ reduction of approximately $80 \%$ (based on $1 \%$ of the $\mathrm{NO}_{\mathrm{x}}$ as $\mathrm{NO}_{2}$, which is the approximate value for the $\mathrm{SCR}$ facility). Due to calibration problems in the ammonia injection system and calibration drift in the venturi flow measurement, the long term effective ammonia-to- $\mathrm{NO}_{\mathrm{x}}$ ratio of the $\mathrm{SCR}$ reactors was approximately 0.90 during the first two quarters of testing. Parametric testing required variations in the ammonia-to- 
$\mathrm{NO}_{\mathrm{x}}$ ratio. During these tests, the effective ammonia-to- $\mathrm{NO}_{\mathrm{x}}$ ratio was varied from a high of approximately 1.2 to a low of approximately 0.7 on each reactor. These parametric tests were conducted over relatively short periods of time and represent only a small fraction of the total reactor operating time.

- Ammonia Distribution

Ammonia distribution within the individual SCR reactors is extremely important in controlling ammonia slip and maintaining reactor efficiency. Assuming a perfectly smooth NOx distribution, it is desirable to maintain an ammonia distribution that is as smooth as possible. The general criteria set for the pilot plant is to maintain ammonia distribution to within $10 \%$ of the average. Ammonia distributions were measured downstream of the dummy bed on each reactor at nine equally spaced points on the large reactors and four on the small reactors. For these measurements, the ammonia injection rate was held constant giving an average ammonia concentration of $155 \mathrm{ppm}$ at standard reactor flow rate. The tests initially showed consistently low concentrations of ammonia across the reactor duct. Subsequent evaluation revealed that reaction of ammonia and NOx was taking place across the sampling probes which were constructed of stainless steel. Replacement of the probes with glass corrected this reaction problem. Subsequent measurements of ammonia distribution showed that all distributions were within the $10 \%$ limit with averages comparing favorably with the predicted value.

\section{- Flue Gas Temperature}

The SCR facility is equipped with an economizer by-pass duct. This allows for high temperature flue gas extracted upstream of the host unit economizer to be mixed with flue gas extracted downstream of the host unit economizer. By adjusting the relative flows of these two components of the pilot plant feed gas, the temperature to the pilot plant can be adjusted. Under normal operation, the flue gas temperature to the pilot plant is maintained at $650^{\circ} \mathrm{F}$. This is possible when the host unit is running at relatively high loads, however, at low unit load, the pilot plant inlet gas temperature often drops below $650^{\circ} \mathrm{F}$ even with full use of the economizer by-pass duct. Also, under some circumstances, while the host unit is operating at very high load, 
the feed gas to the pilot plant may exceed $650^{\circ} \mathrm{F}$ even with no economizer by-pass gas being used. The average flue gas temperature to the test facility as well as the daily high and low temperature are shown below for this reporting period. As with the previously shown gas concentration data, this data is constructed using daily averages, daily highs, and daily lows, during periods of on-line host boiler operation.

\section{Test Facility Inlet Gas Temperature $\left({ }^{\circ} \mathrm{F}\right)$}

\section{Oct.-Dec. '93}

\section{Average High $\underline{\text { Low }}$}

$650 \quad 675 \quad 624$

Each reactor is equipped with a flue gas heater which maintains strict control over the temperature of the flue gas entering the reactors. Under normal operating conditions the flue gas is maintained at $700^{\circ} \mathrm{F}$ at the entrance to the reactors. This requires that the gas be heated from approximately $650^{\circ} \mathrm{F}$ to $700^{\circ} \mathrm{F}$ under normal operating conditions. Of course, heat loss in the system requires some additional flue gas heating over the $50^{\circ} \mathrm{F}$ temperature difference noted. Under parametric conditions, the flue gas temperature to the reactors is varied from a low of approximately $620^{\circ} \mathrm{F}$ to a high of $750^{\circ} \mathrm{F}$. Under these conditions, the economizer bypass duct flow rate may be adjusted to assist the heaters in obtaining the appropriate temperature. Under high temperature parametric conditions, heat loss through the system is more apparent, and flue gas temperatures of $780^{\circ} \mathrm{F}$ just downstream of the heater may be required to give $750^{\circ} \mathrm{F}$ at the reactor inlet. Lower temperature parametric conditions do not show as extreme a temperature loss between the heaters and the inlet to the reactors. As a result, the heater exit temperature is normally much closer to the reactor inlet gas temperature during low temperature parametric tests and normal operating conditions.

\section{- Air Preheater Performance Data}

The three large reactors of the SCR facility are each equipped with an air preheater. Reactor A is equipped with a trisector Lungstrum type rotary air preheater supplied by ABB Air Preheater, Inc. of Wellsville, New York. Reactor B is equipped with a bisector rotary air preheater nearly identical to the A preheater, also supplied by $A B B$. Reactor $C$ is equipped with an $A B B$ Q-pipe which is a heat pipe design utilizing toluene and naphthalene as the working fluids. The original design of the SCR facility included air preheater bypass ducting which allowed the air preheaters to be bypassed during any condition other than normal operating conditions. This was done to 
insure that the air preheater's long-term fouling characteristics were not skewed by extreme conditions during some of the short term parametric tests. The large reactor fan design requires relatively cool gas (less than $350^{\circ} \mathrm{F}$ ). To accommodate this restriction, the air preheater bypass ducting was equipped with heat exchangers which were designed to cool the flue gas in place of the air preheaters. Unfortunately, the design of the by-pass heat exchangers caused immediate fouling upon use, making it unsatisfactory for the application. Consequently, the SCR facility is forced to use the three large reactor air preheaters at all times when on-line to maintain proper flue gas conditions for the large reactor fans. As a result, the air preheaters are exposed to the harsh conditions created by some of the parametric tests. However, these test periods are very short compared to the overall operating time at standard conditions, and it is assumed that overall fouling characteristics of the air preheaters are not greatly affected by the current operational requirements. Table 3 shows the average operating parameters for the three air preheaters over the reporting period shown and these values include any parametric test conditions that were performed during the specific time period. 
TABLE 3.

AVERAGE AIR PREHEATER OPERATIONAL PARAMETERS, OCT.-DEC. 1993

\begin{tabular}{|c|c|c|c|}
\hline Parameter & APH A & $\mathrm{APHB}$ & $\mathrm{APHC}$ \\
\hline Gas flow rate (SCFM) & 4544 & 4629 & 5226 \\
\hline Air flow rate (SCFM) & 4026 & 3500 & 6010 \\
\hline Inlet gas temp. $\left({ }^{\circ} \mathrm{F}\right)$ & 663 & 661 & 664 \\
\hline Exit gas temp. $\left({ }^{\circ} \mathrm{F}\right)$ & 313 & 308 & 307 \\
\hline Inlet air temp. $\left({ }^{\circ} \mathrm{F}\right)$ & 73 & 73 & 73 \\
\hline Exit air temp. $\left({ }^{\circ} \mathrm{F}\right)$ & 605 & 588 & 508 \\
\hline Gas side press. drop $\left(" \mathrm{H}_{2} \mathrm{O}\right)$ & 4.31 & 5.27 & 2.31 \\
\hline Air side press. drop $\quad\left(" \mathrm{H}_{2} \mathrm{O}\right)$ & 1.87 & 1.75 & NA \\
\hline Air/Gas diff. press. $\quad\left(" \mathrm{H}_{2} \mathrm{O}\right)$ & 0.48 & 0.48 & NA \\
\hline Inlet gas $\mathrm{O}_{2} \quad$ (\% wet) & 5.24 & 5.84 & 5.79 \\
\hline Exit gas $\mathrm{O}_{2} \quad$ (\% wet) & 6.89 & 7.72 & NA \\
\hline
\end{tabular}

- Catalyst-Specific Performance Parameters

Although resolved late in this quarter, problems with the gas analysis system, ammonia flow control, air inleakage, and ammonia-to- $\mathrm{NO}_{\mathrm{x}}$ ratio control limited collection of long-term data, as noted previously. The Reactor A - C first parametric test data were reported in the previous quarter's results. There was no parametric test data taken on Reactors $\mathrm{G}-\mathrm{J}$ because of the physical catalyst failure for Reactor $\mathrm{G}$ and because Engelhard withdrew from the project 
(Reactors $\mathrm{H}$ and $\mathrm{J}$ ). The parametric test results for Reactors $\mathrm{D}$ - F for this reporting period are discussed in the following sections.

Overall reactor pressure drops (inlet to outlet, including dummy layer and all catalysts) are shown in Figure 3 for Reactors A - G. In general, the pressure drops ranged from 2 to 5 inches of water. The Siemens catalyst displayed the lowest pressure drop during the quarter of 2 inches of water. The Hitachi Zosen catalyst in Reactor $G$ had the highest pressure drop of over 8 inches of water as a result of the physical catalyst failure, as described earlier in this report.

\section{- Reactor D}

Table 4 shows the performance of the catalyst at or near the design operating conditions of 0.8 ammonia-to- $\mathrm{NO}_{\mathrm{x}}$ ratio, $400 \mathrm{SCFM}$ flow rate, and $700^{\circ} \mathrm{F}$ reactor temperature. As can be seen in the table, the actual measured ammonia-to- $\mathrm{NO}_{\mathrm{x}}$ ratio is greater than 0.8 . This is primarily the result of some miscalibrations in both flow rate and ammonia injection rate, creating a higher than desired ammonia-to- $\mathrm{NO}_{\mathrm{x}}$ ratio. This higher ratio, however, has one beneficial effect in that it creates ammonia slip values that are well within the ammonia sampling method detection range. Slip values measured at 0.8 ammonia-to- $\mathrm{NO}_{\mathrm{x}}$ ratio are expected to be near or below detection limits. Slips within the detection limits allow for more accurate comparisons between catalysts and also allow for more accurate reactor modeling to be performed. Also included in the table is the baseline $\mathrm{SO}_{2}$ oxidation rate and the corresponding reactor conditions for the measurement. Ammonia slip and $\mathrm{SO}_{2}$ oxidation are not typically measured simultaneously and therefore the reactor operating conditions differ slightly for the reported slip and $\mathrm{SO}_{2}$ oxidation values.

\section{TABLE 4. BASELINE PERFORMANCE}

$\begin{array}{lllllll}\begin{array}{l}\text { Flow Rate } \\ (\mathrm{SCFM})\end{array} & \begin{array}{l}\text { Temp. } \\ \left({ }^{\circ} \mathrm{F}\right)\end{array} & \begin{array}{l}\mathrm{NO}_{\mathrm{x}} \mathrm{IN} \\ (\text { ppmv) }\end{array} & \begin{array}{l}\mathrm{NH} 3 / \mathrm{NO}_{\mathrm{x}} \\ \text { Ratio }\end{array} & \begin{array}{l}\mathrm{NH}_{3} \text { Slip } \\ (\text { ppmv) }\end{array} & \begin{array}{l}\mathrm{NO}_{\mathrm{x}} \text { Red. } \\ (\%)\end{array} & \begin{array}{l}\mathrm{SO}_{2} \mathrm{Ox} . \\ (\%)\end{array} \\ 372 & 700 & 300 & .951 & 0.9 & 93 \% & - \\ 373 & 700 & 295 & .951 & & 93 \% & 0.80\end{array}$

The majority of the ammonia measurements during the preliminary parametric tests focused on concentrations downstream of the first catalyst bed. These measurements were made as part of a series of statistically designed tests which varied flow rate, temperature, and ammonia-to- $\mathrm{NO}_{\mathrm{x}}$ 

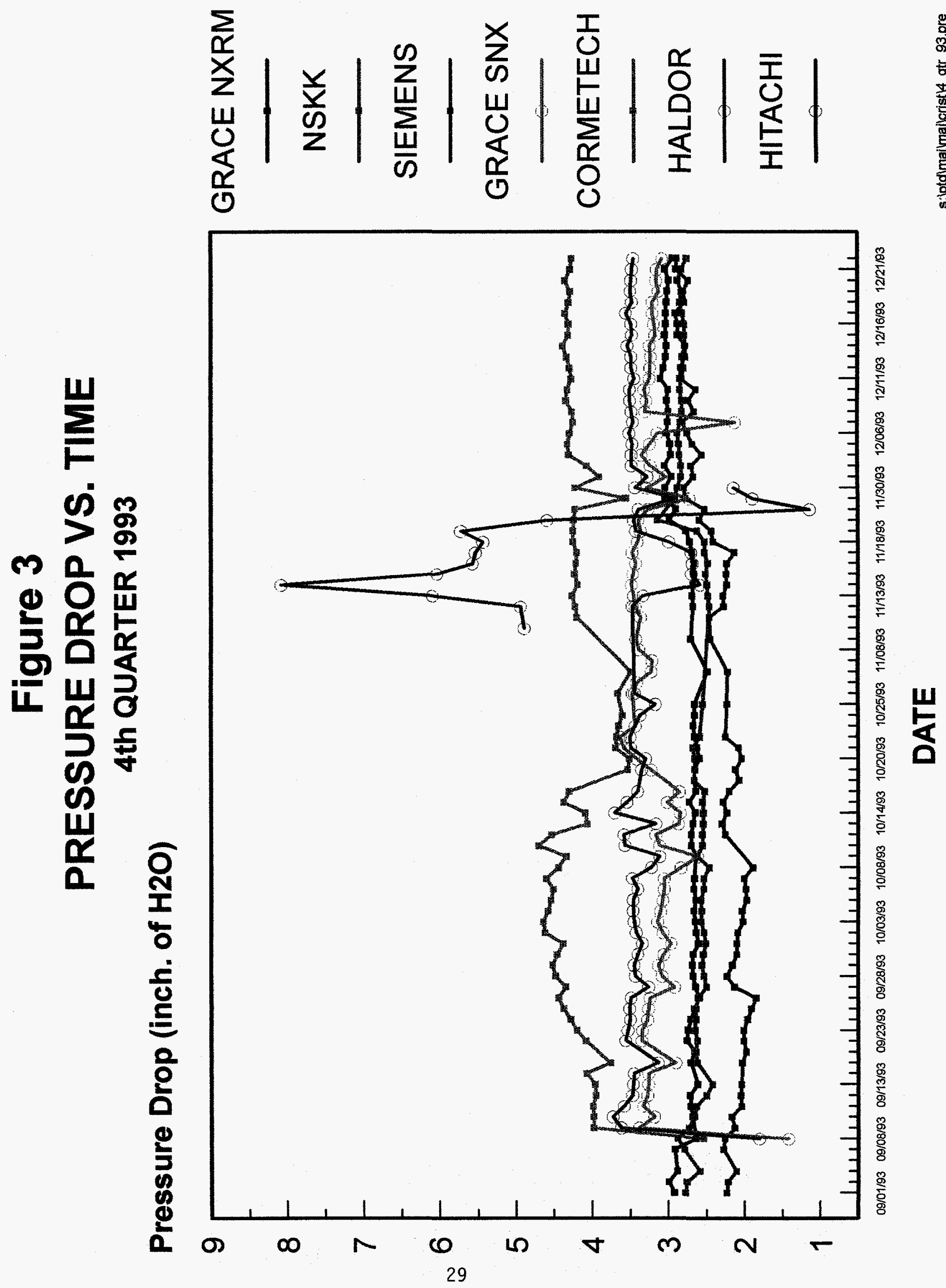
ratio. Each of these parameters was varied using a high and low value. Thus, eight permutations are created which correspond to the eight test conditions for this portion of the parametric tests. The results of this series of tests are shown as a plot of $\mathrm{NO}_{\mathrm{x}}$ removal across the first catalyst bed versus ammonia-to- $\mathrm{NO}_{\mathrm{x}}$ ratio in Figure 4. Test procedures called for the measurement of ammonia, which is used in the kinetic analyses. The reported $\mathrm{NO}_{\mathbf{x}}$ removals for the plot shown below are computed from the measured ammonia concentration using standard material balance techniques.

The following table shows the data used to generate the previous plot. Also included is base line intermediate ammonia data. The data are presented in terms of intermediate ammonia concentrations, which is the measured parameter. All data is corrected to reactor inlet oxygen concentrations.

\section{TABLE 5. INTERMEDIATE AMMONIA PARAMETRIC TEST DATA}

$\begin{array}{llllll}\begin{array}{l}\text { Flow } \\ \begin{array}{l}\text { Rate } \\ \text { (SCFM) }\end{array}\end{array} & \begin{array}{l}\text { Temp. } \\ \left({ }^{\circ} \mathrm{F}\right)\end{array} & \begin{array}{l}\text { Inlet } \mathrm{O}_{2} \\ \text { (\%) }\end{array} & \begin{array}{l}\text { Inlet } \mathrm{NO}_{\mathrm{x}} \\ \text { (ppmv) }\end{array} & \begin{array}{l}\mathrm{NH}_{3} / \mathrm{NO}_{\mathbf{x}} \\ \text { Ratio }\end{array} & \begin{array}{l}\text { Int. } \mathrm{NH}_{3} \\ \text { (ppmv) }\end{array} \\ 224 & 620 & 6.083 & 306 & 0.713 & 7.9 \\ 230 & 620 & 5.794 & 322 & 1.190 & 29.1 \\ 532 & 620 & 5.151 & 272 & 0.696 & 28.2 \\ 559 & 620 & 6.204 & 303 & 0.969 & 101.5 \\ 351 & 700 & 6.335 & 315 & 0.994 & 22.4 \\ 228 & 750 & 6.067 & 309 & 0.714 & 5.6 \\ 226 & 750 & 2.990 & 241 & 1.207 & 12.5 \\ 556 & 750 & 3.419 & 258 & 0.702 & 25.0 \\ 560 & 750 & 3.638 & 237 & 1.202 & 67.7\end{array}$

Parametric tests were also performed to determine the sulfur dioxide oxidation characteristics of the catalyst. The operating parameters of the reactor were varied in an identical fashion to the intermediate ammonia parametric tests. Thus, eight specific parametric tests were performed in addition to the base line test. The data is presented in two plots, Figure 5 showing the effect of flow rate on sulfur dioxide oxidation, and Figure 6 showing the effect of temperature on sulfur dioxide oxidation. The flow rate effect data is based on high temperature data, with two lines shown, one for high ammonia-to- $\mathrm{NO}_{\mathrm{x}}$ ratio, and one for low ammonia-to- $\mathrm{NO}_{\mathrm{x}}$ ratio. The temperature effect is based on low ammonia-to- $\mathrm{NO}_{\mathrm{x}}$ ratio data, with two lines shown, one for 
Figure 4

\section{FIRST BED NOx RED. vs. NH3/NOx RATIO}

4th QUARTER 1993

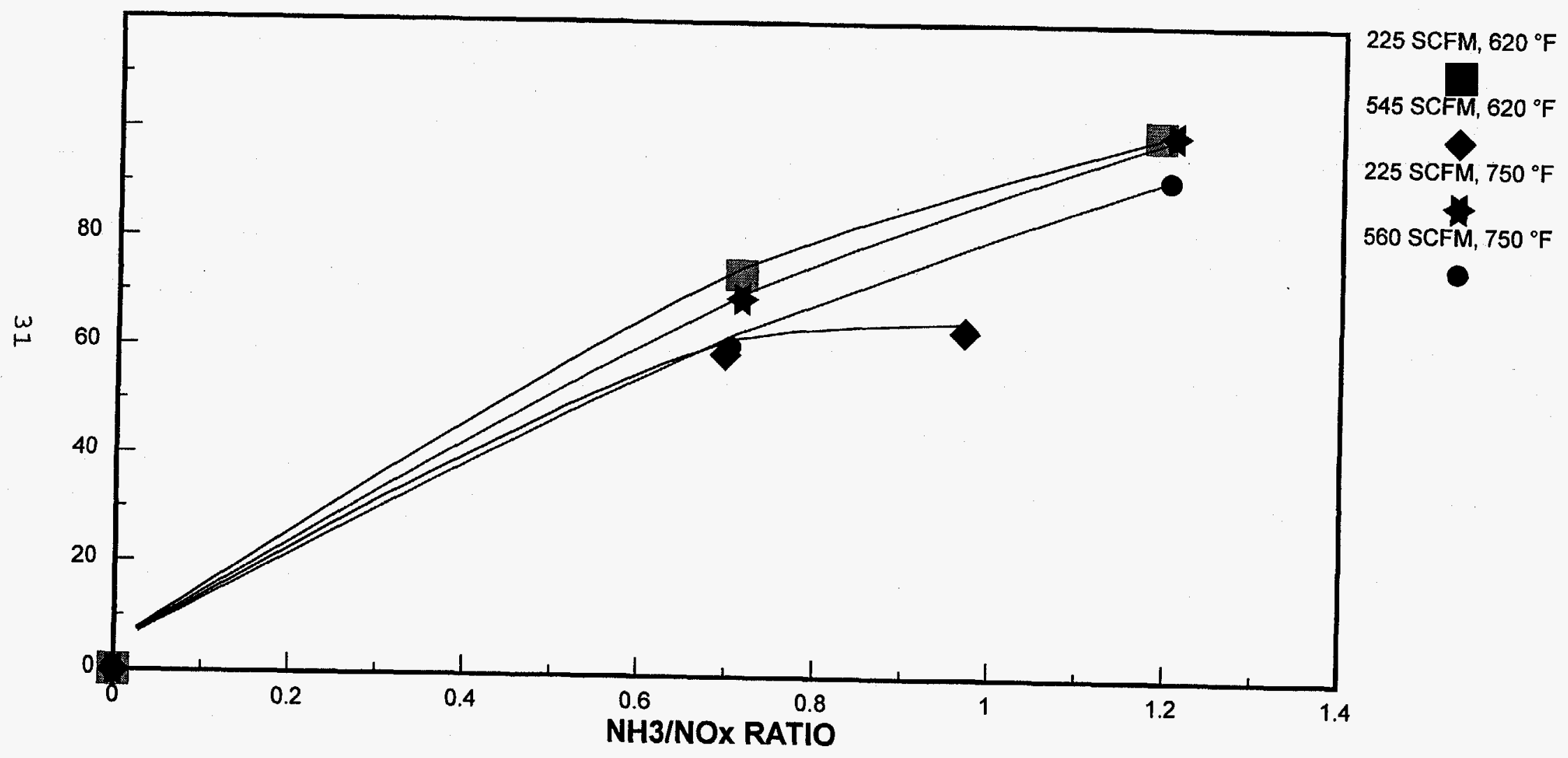


Figure 5

\section{SO2 OXIDATION VS. FLOW RATE}

4th QUARTER 1993

SO2 OXIDATION (\%)

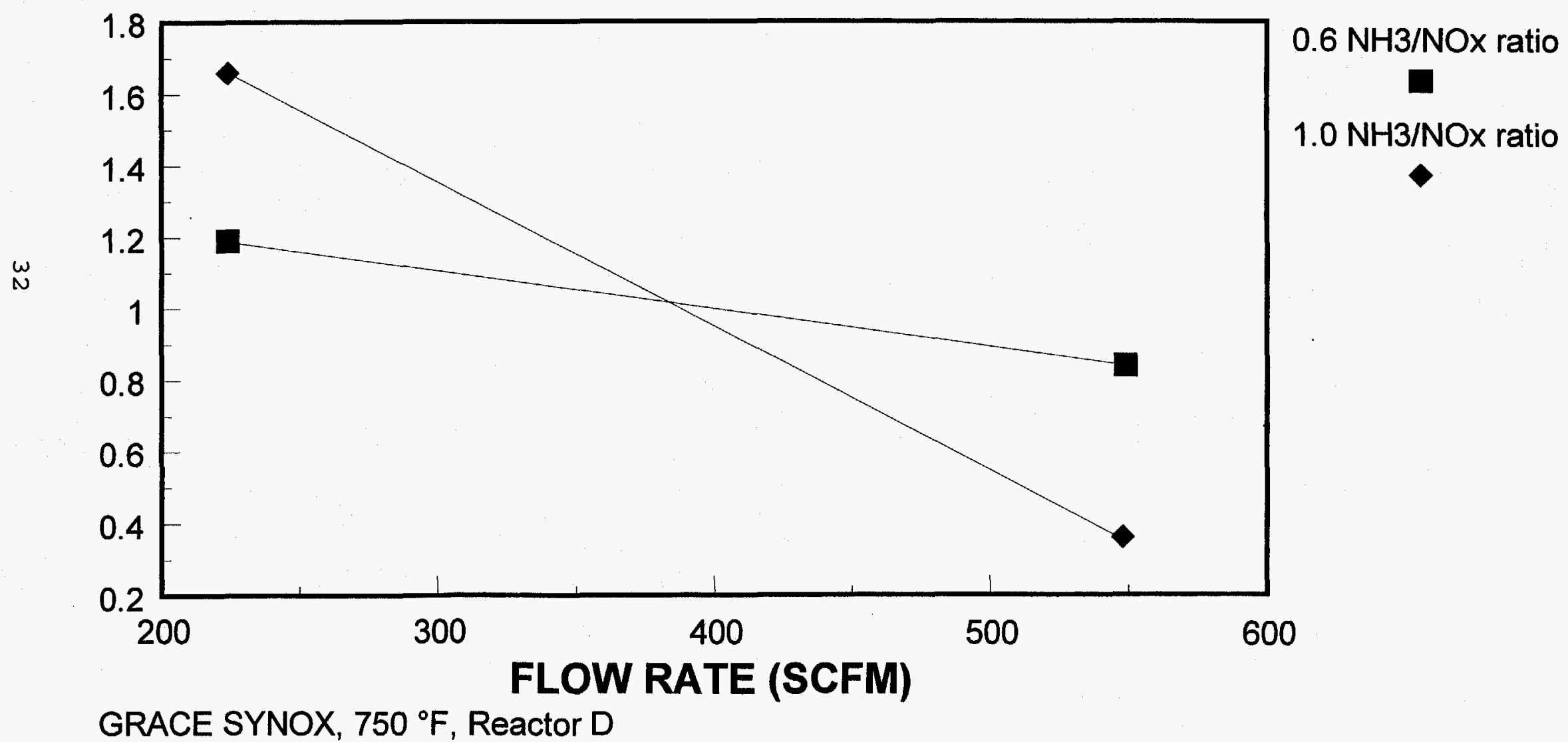


Figure 6

\section{SO2 OXIDATION VS. TEMPERATURE}

\section{SO2 OXIDATION (\%)}

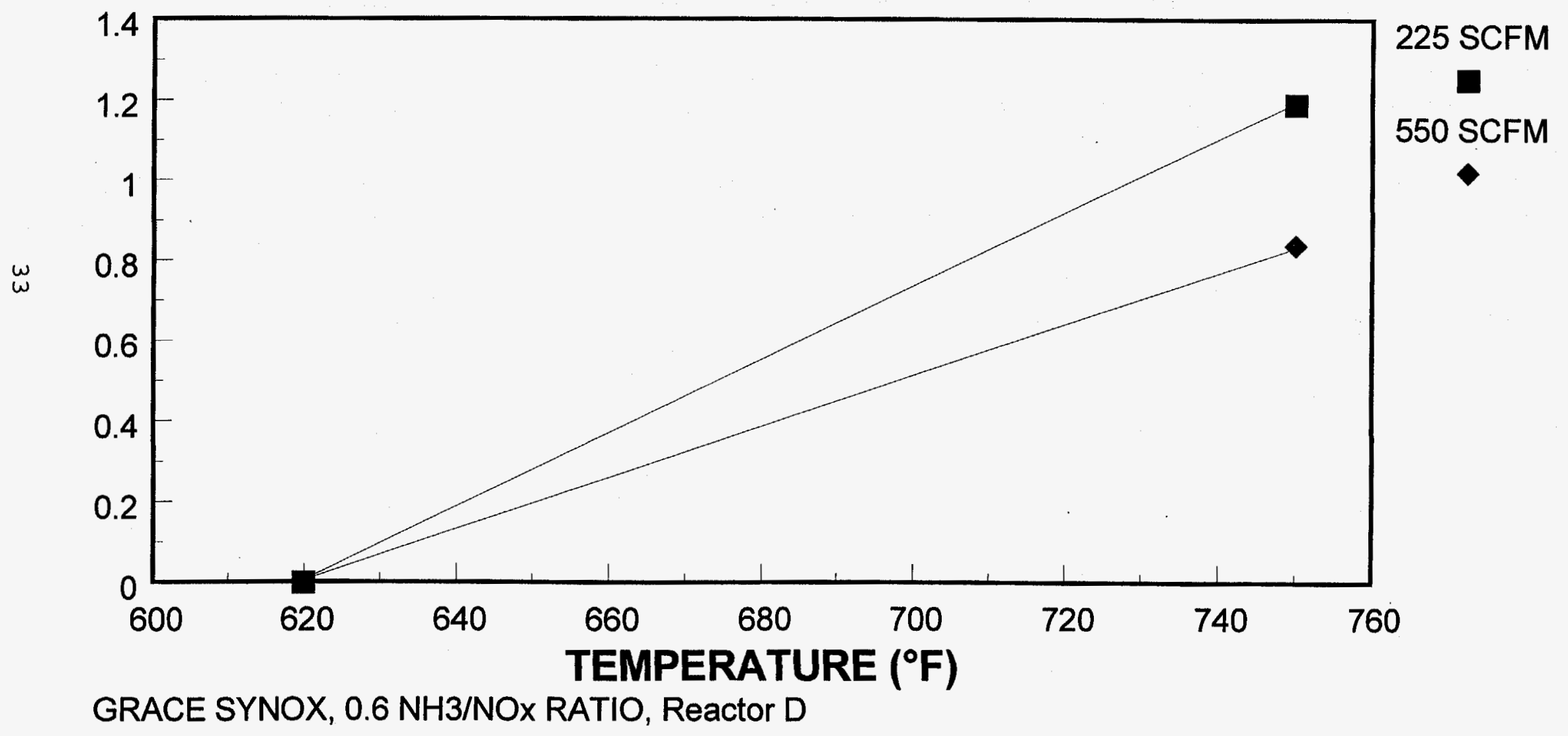


high flow rate, and one for low flow rate. The plots show a definite ammonia-to-NO $\mathrm{N}_{\mathrm{x}}$ ratio effect on the sulfur dioxide oxidation characteristics of the catalyst. However, this effect is not thought to be a true catalytic effect, but is actually a precipitation effect. Earlier studies with no catalyst present showed that sulfur trioxide was lost through the reactor, most likely in cold spots such as test ports, etc. The presence of ammonia may affect this precipitation phenomenon. Most likely this occurs by changing the precipitation characteristics of the sulfur trioxide through the formation of byproducts such as ammonium bisulfate in the cold spots of the reactor.

Similar to the previously shown table of intermediate ammonia data, Table 6 shows the sulfur dioxide oxidation data for each of the parametric conditions that were tested. This data is corrected to reactor outlet oxygen concentrations. The value for sulfur trioxide produced in the reactor is based on the measured outlet sulfur trioxide concentration and estimated sulfur trioxide reactor inlet values. The reactor inlet sulfur trioxide values are estimated using past measurements of inlet sulfur trioxide based on host boiler load. In many cases, especially those involving low temperature conditions, there was no net increase in sulfur trioxide concentrations across the reactor. In fact, some operating conditions showed a loss in sulfur trioxide across the reactor in addition to the loss that normally occurs without catalyst present. In these cases, the sulfur dioxide oxidation rate is taken to be zero. (Tables showing $\mathrm{SO}_{2}$ oxidation rates quote reactor flow rates as calculated for the reactor exit, since $\mathrm{SO}_{3}$ is measured at this point. For consistency with other figures, the plots of $\mathrm{SO}_{2}$ oxidation versus flowrate are based on reactor inlet flowrates. In practice, differences between inlet and outlet flowrates are slight and do not greatly affect the overall analysis.)

\section{TABLE 6. SULFUR DIOXIDE OXIDATION PARAMETRIC TEST DATA}

\begin{tabular}{|c|c|c|c|c|c|c|c|c|}
\hline $\begin{array}{l}\text { Flow } \\
\text { Rate } \\
\text { (SCFM) }\end{array}$ & $\begin{array}{l}\text { Operating } \\
\text { Temp. } \\
\left({ }^{\circ} \mathrm{F}\right)\end{array}$ & $\begin{array}{l}\text { Outlet } \\
\mathrm{O}_{2} \\
(\%)\end{array}$ & $\begin{array}{l}\text { Inlet } \\
\mathrm{SO}_{2} \\
\text { (ppmv) }\end{array}$ & $\begin{array}{l}\mathrm{NH}_{3} / \\
\mathrm{NO}_{x} \\
\text { Ratio }\end{array}$ & $\begin{array}{l}\mathrm{SO}_{3} \\
\text { formed } \\
\text { (ppmv) }\end{array}$ & $\begin{array}{l}\text { Predicted/ } \\
\mathrm{SO}_{3} \text { in } \\
\text { (ppmv) }\end{array}$ & $\begin{array}{l}\text { Measured/ } \\
\mathrm{SO}_{3} \text { out } \\
\text { (ppmv) }\end{array}$ & $\begin{array}{l}\text { Oxid. } \\
\text { Rate } \\
\text { \%) }\end{array}$ \\
\hline 298 & $620^{\circ} \mathrm{F}$ & 8.089 & 1420 & 0.715 & -2 & 6.9 & 5.0 & 0 . \\
\hline 287 & $750^{\circ} \mathrm{F}$ & 7.689 & 1441 & 0.721 & 17 & 6.3 & 23.4 & 1.19 \\
\hline 289 & $750^{\circ} \mathrm{F}$ & 7.960 & 1568 & 1.207 & 26 & 6.6 & 32.7 & 1.66 \\
\hline 555 & $750^{\circ} \mathrm{F}$ & 4.371 & 1663 & 0.721 & 14 & 7.5 & 21.5 & 0.84 \\
\hline 568 & $750^{\circ} \mathrm{F}$ & 5.009 & 1572 & 1.187 & 6 & 8.4 & 14.1 & 0.36 \\
\hline
\end{tabular}


The pressure drop across the reactor is another important criteria for SCR usage because of its effect on fan horsepower requirements, the single largest energy need for the SCR process. Typical reactor pressure drop is shown in Figure 3.

Mass concentrations and flue gas velocity profiles were conducted at an 84-MW boiler load for the design operating condition $\left(700^{\circ} \mathrm{F}, 100 \%\right.$ flow rate $[400 \mathrm{scfm}]$, and $\mathrm{NH}_{3} / \mathrm{NO}_{\mathrm{x}}$ ratio of 0.8$)$. The mass concentration profile data is given in Figure 7 in four different units of concentration and as mass emission rate. The average mass concentration were $1.14 \mathrm{gr} / \mathrm{acf}, 2.89 \mathrm{gr} / \mathrm{dscf}, 2,626$ $\mathrm{mg} / \mathrm{acm}$, and $6,620 \mathrm{mg} / \mathrm{dscm}$ (with a relative standard deviation of $8 \%$ ); and the average emission rate was $4.87 \mathrm{lb} / \mathrm{MBtu}$. The flue gas velocity profile is presented in Figure 8 . The average velocity was $11.6 \pm 0.4 \mathrm{ft} / \mathrm{sec}^{1}$

$\mathrm{HCl}$ concentration was also measured at the design operating condition. The three test results and resulting average $\mathrm{HCl}$ concentration (at $3 \% \mathrm{O}_{2}$, wet) were as follows: ${ }^{1}$

\section{$\mathrm{HCl}$ concentration, ppmv}

Sample 1

Sample 2

Sample 3

Average

- Reactor E
134

120

119

$124 \pm 8.7$

Table 7 shows the performance of the catalyst at or near the design operating conditions of 0.8 ammonia-to- $\mathrm{NO}_{\mathrm{x}}$ ratio, $400 \mathrm{SCFM}$ flow rate, and $700^{\circ} \mathrm{F}$ reactor temperature. As can be seen in the table, the actual measured ammonia-to- $\mathrm{NO}_{\mathrm{x}}$ ratio is greater than 0.8 . This is primarily the result of some miscalibrations in both flow rate and ammonia injection rate, creating a higher than desired ammonia-to- $\mathrm{NO}_{\mathrm{x}}$ ratio. This higher ratio, however, has one beneficial effect in that it creates ammonia slip values that are well within the ammonia sampling method detection range. Slip values measured at 0.8 ammonia-to- $\mathrm{NO}_{\mathrm{x}}$ ratio are expected to be near or below detection limits. Slips within the detection limits allow for more accurate comparisons between catalysts and also allow for more accurate reactor modeling to be performed. Also included in the table is the baseline $\mathrm{SO}_{2}$ oxidation rate and the corresponding reactor conditions for the measurement. Ammonia slip and $\mathrm{SO}_{2}$ oxidation are not typically measured simultaneously and therefore the reactor operating conditions differ slightly for the reported slip and $\mathrm{SO}_{2}$ oxidation values. 
Figure 7. Mass concentration and mass emission rate profiles at the Reactor $\mathrm{D}$ outlet.
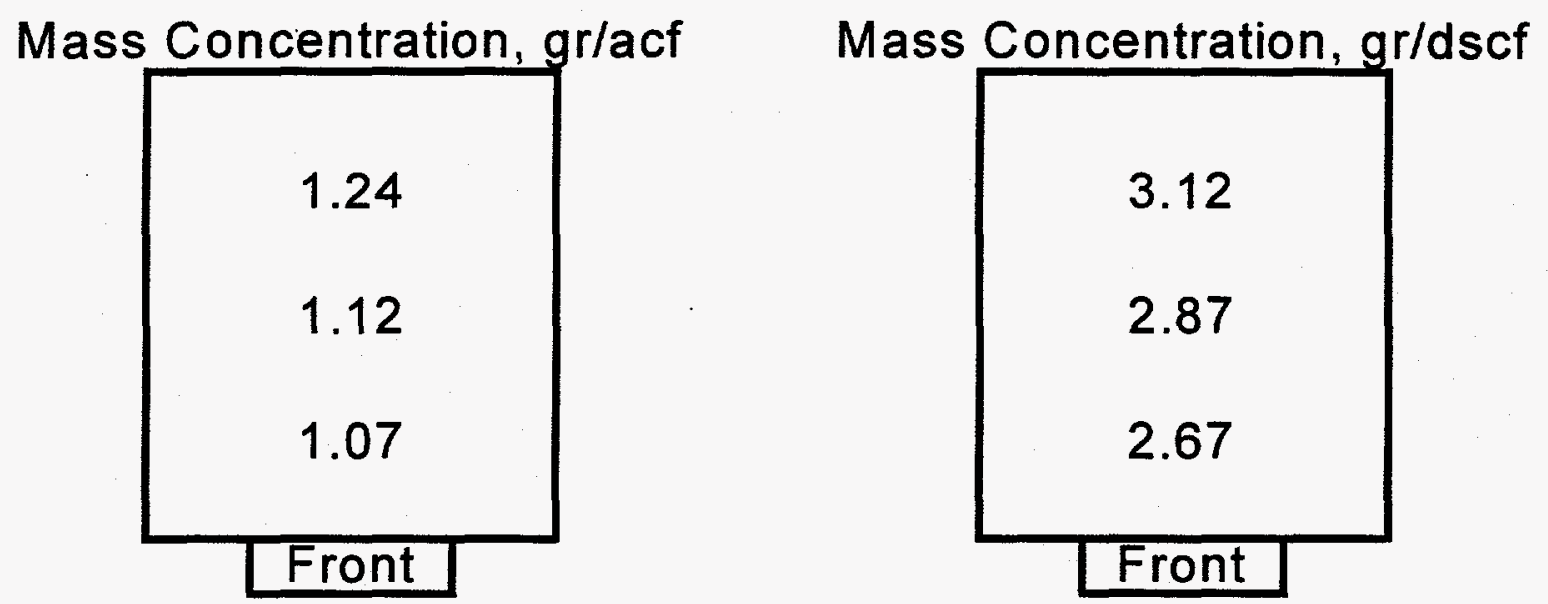

Mass Concentration, $\mathrm{mg} / \mathrm{acm}$

\begin{tabular}{|c|}
\hline 2,850 \\
2,560 \\
2,460 \\
\hline
\end{tabular}

Mass Concentration, $\mathrm{mg} / \mathrm{dscm}$

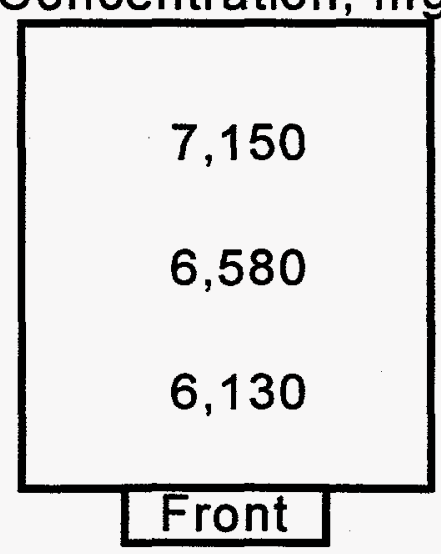

Mass Emission Rate, Ib/MBtu

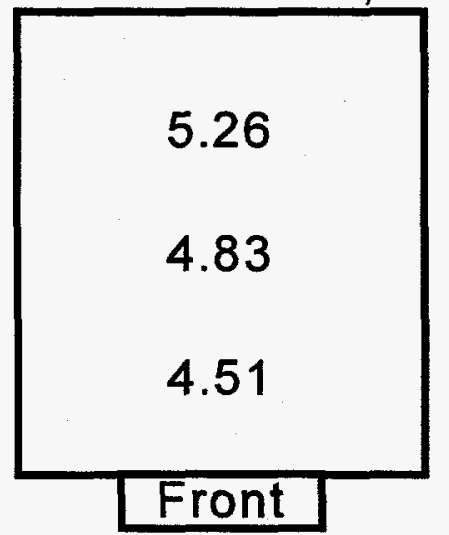

s:Lptdimajimajldm070695.pre 
Figure 8. Flue gas velocity profile at the Reactor $\mathrm{D}$ outlet.

Flue Gas Velocity, ft/s

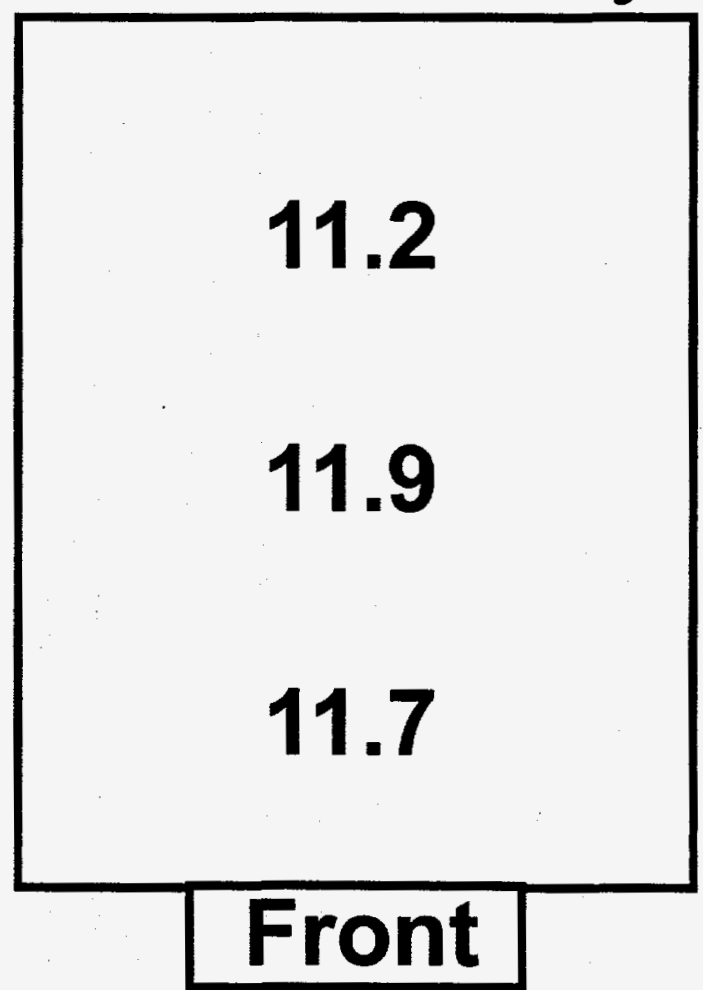




\section{TABLE 7. BASELINE PERFORMANCE}

\begin{tabular}{lllllll}
$\begin{array}{l}\text { Flow Rate } \\
(\mathrm{SCFM})\end{array}$ & $\begin{array}{l}\text { Temp. } \\
(\mathrm{OF})\end{array}$ & $\begin{array}{l}\mathrm{NO}_{\mathrm{x}} \mathrm{In} \\
(\mathrm{ppmv})\end{array}$ & $\begin{array}{l}\mathrm{NH} 3 \mathrm{NO}_{\mathrm{x}} \\
\text { Radio }\end{array}$ & $\begin{array}{l}\mathrm{NH}_{3} \mathrm{Slip} \\
(\mathrm{ppmv})\end{array}$ & $\begin{array}{l}\mathrm{NO}_{\mathrm{x}} \text { Red. } \\
(\%)\end{array}$ & $\begin{array}{l}\mathrm{SO}_{2} \mathrm{Ox} . \\
(\%)\end{array}$ \\
\hline 373 & 700 & 305 & 0.938 & $<0.8$ & $92 \%$ & - \\
373 & 700 & 294 & 0.950 & -- & $93 \%$ & 0.43
\end{tabular}

The majority of the ammonia measurements during the preliminary parametric tests focused on concentrations downstream of the first catalyst bed. These measurements were made as part of a series of statistically designed tests which varied flow rate, temperature, and ammonia-to- $\mathrm{NO}_{\mathrm{x}}$ ratio. Each of these parameters was varied using a high and low value. Thus, eight permutations are created which correspond to the eight test conditions for this portion of the parametric tests. The results of this series of tests are shown as a plot of $\mathrm{NO}_{\mathrm{x}}$ removal across the first catalyst bed versus ammonia-to- $\mathrm{NO}_{\mathrm{x}}$ ratio in Figure 9. Test procedures called for the measurement of ammonia, which is used in the kinetic analyses. The reported $\mathrm{NO}_{\mathbf{x}}$ removals for the plot shown below are computed from the measured ammonia concentration using standard material balance techniques.

Table 8 shows the data used to generate the previous plot. Also included is base line intermediate ammonia data. The data are presented in terms of intermediate ammonia concentrations, which is the measured parameter. All data is corrected to reactor inlet oxygen concentrations.

\section{TABLE 8. INTERMEDIATE AMMONIA PARAMETRIC TEST DATA}

$\begin{array}{llllll}\begin{array}{l}\text { Flow Rate } \\ (\mathrm{SCFM})\end{array} & \begin{array}{l}\text { Temp. } \\ \left({ }^{\circ} \mathrm{F}\right)\end{array} & \begin{array}{l}\text { Inlet } \mathrm{O}_{2} \\ (\%)\end{array} & \begin{array}{l}\text { Inlet } \mathrm{NO}_{\mathbf{x}} \\ \text { (ppmv) }\end{array} & \begin{array}{l}\mathrm{NH}_{3} / \mathrm{NO}_{\mathbf{x}} \\ \text { Ratio }\end{array} & \begin{array}{l}\text { Int. } \mathrm{NH}_{3} \\ \text { (ppmv) }\end{array} \\ 223 & 620 & 3.655 & 279 & 0.695 & 2.6 \\ 222 & 620 & 5.563 & 265 & 1.117 & 3.6 \\ 565 & 620 & 5.320 & 286 & 0.666 & 14.2 \\ 558 & 620 & 3.026 & 274 & 1.156 & 90.6 \\ 366 & 700 & 4.314 & 280 & 0.940 & 11.8 \\ 226 & 750 & 3.504 & 250 & 0.713 & 1.3 \\ 227 & 750 & 3.718 & 237 & 1.199 & 4.4 \\ 544 & 750 & 5.969 & 292 & 0.665 & 10.8 \\ 559 & 750 & 2.934 & 242 & 1.202 & 41.1\end{array}$


Figure 9

\section{FIRST BED NOx RED. vs. NH3/NOx RATIO}

4th QUARTER 1993

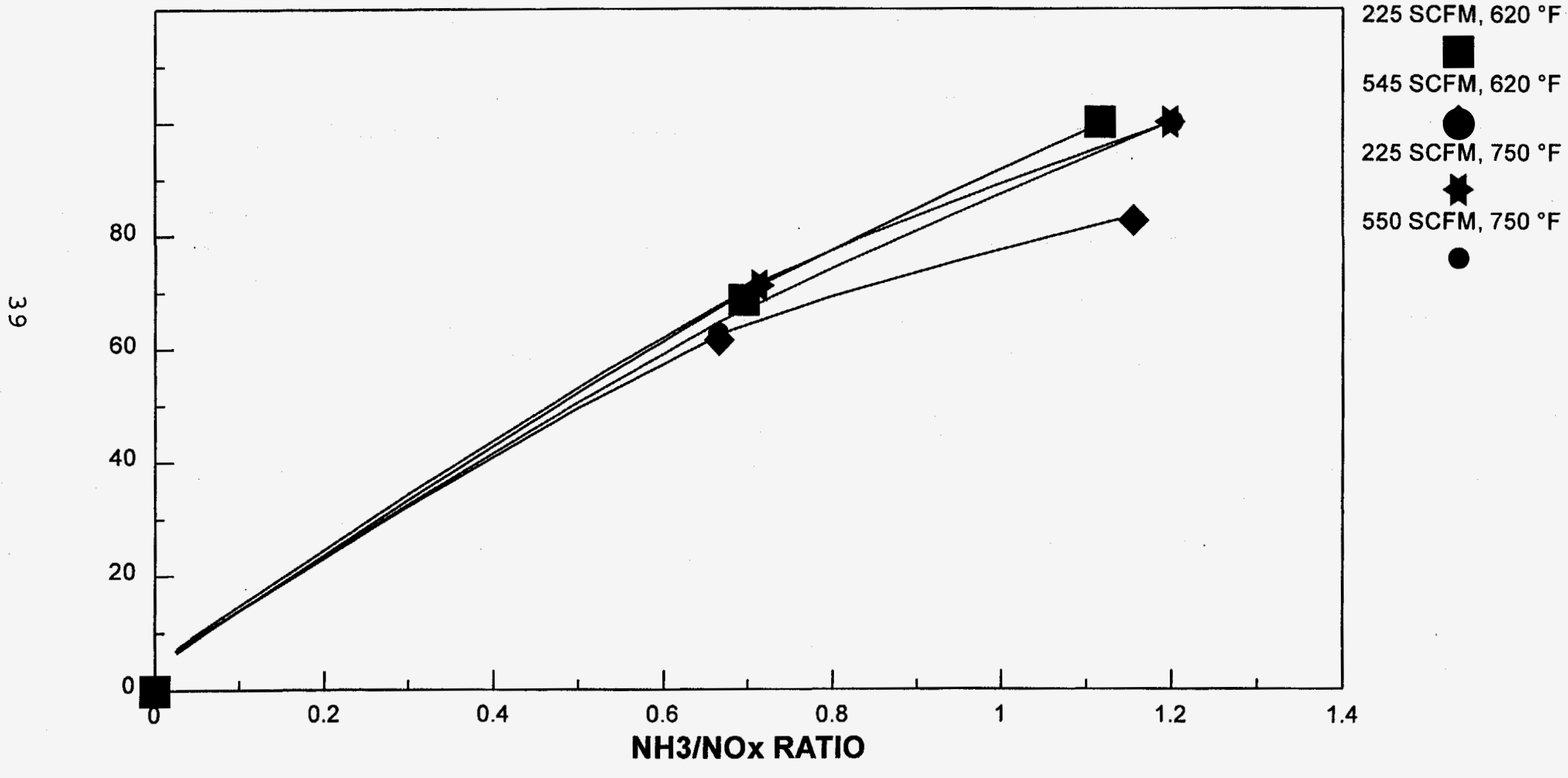


Parametric tests were also performed to determine the sulfur dioxide oxidation characteristics of the catalyst. The operating parameters of the reactor were varied in an identical fashion to the intermediate ammonia parametric tests. Thus, eight specific parametric tests were performed in addition to the base line test. The data is presented in two plots, Figure 10 showing the effect of flow rate on sulfur dioxide oxidation, and Figure 11 showing the effect of temperature on sulfur dioxide oxidation. The flow rate effect data is based on high temperature data, with two lines shown, one for high ammonia-to- $\mathrm{NO}_{\mathrm{x}}$ ratio, and one for low ammonia-to- $\mathrm{NO}_{\mathrm{x}}$ ratio. The temperature effect is based on low ammonia-to- $\mathrm{NO}_{\mathrm{x}}$ ratio data, with two lines shown, one for high flow rate, and one for low flow rate. The plots show a definite ammonia-to- $\mathrm{NO}_{\mathrm{x}}$ ratio effect on the sulfur dioxide oxidation characteristics of the catalyst. However, this effect is not thought to be a true catalytic effect, but is actually a precipitation effect. Earlier studies with no catalyst present showed that sulfur trioxide was lost through the reactor, most likely in cold spots such as test ports, etc. The presence of ammonia may affect this precipitation phenomenon. Most likely this occurs by changing the precipitation characteristics of the sulfur trioxide through the formation of byproducts such as ammonium bisulfate in the cold spots of the reactor. Similar to the previously shown table of intermediate ammonia data, Table 9 shows the sulfur dioxide oxidation data for each of the parametric conditions that were tested. This data is corrected to reactor outlet oxygen concentrations. The value for sulfur trioxide produced in the reactor is based on the measured outlet sulfur trioxide concentration and estimated sulfur trioxide reactor inlet values. The reactor inlet sulfur trioxide values are estimated using past measurements of inlet sulfur trioxide based on host boiler load. In many cases, especially those involving low temperature conditions, there was no net increase in sulfur trioxide concentrations across the reactor. In fact, some operating conditions showed a loss in sulfur trioxide across the reactor in addition to the loss that normally occurs without catalyst present. In these cases, the sulfur dioxide oxidation rate is taken to be zero. (Tables showing $\mathrm{SO}_{2}$ oxidation rates quote reactor flow rates as calculated for the reactor exit, since $\mathrm{SO}_{3}$ is measured at this point. For consistency with other figures, the plots of $\mathrm{SO}_{2}$ oxidation versus flowrate are based on reactor inlet flowrates. In practice, differences between inlet and outlet flowrates are slight and do not greatly affect the overall analysis.) 


\section{TABLE 9. SULFUR DIOXIDE OXIDATION PARAMETRIC TEST DATA}

\begin{tabular}{|c|c|c|c|c|c|c|c|}
\hline Flow & Operating & Outlet & Inlet & $\mathrm{NH}_{3} /$ & $\mathrm{SO}_{3}$ & Predicted/ & Measured/ \\
\hline Rate & Temp. & $\mathrm{O}_{2}(\%)$ & $\mathrm{SO}_{2}$ & $\mathrm{NO}_{\mathrm{x}}$ & Formed & $\mathrm{SO}_{3}$ in & $\mathrm{SO}_{3}$ out \\
\hline (SCFM) & $\left({ }^{\circ} \mathrm{F}\right)$ & $(\%)$ & (ppmv) & Ratio & (ppmv) & (ppmv) & (ppmv) \\
\hline 267 & 620 & 6.683 & 1884 & 0.722 & 0 & 6.9 & 6.3 \\
\hline 257 & 750 & 6.312 & 2043 & 0.728 & 29 & 6.6 & 35.1 \\
\hline 254 & 750 & 6.324 & 2027 & 1.220 & 8 & 6.6 & 14.5 \\
\hline 592 & 750 & 4.930 & 1768 & 0.689 & 6 & 7.5 & 13.7 \\
\hline 578 & 750 & 5.559 & 1660 & 1.171 & 0 & 8.4 & 8.9 \\
\hline
\end{tabular}


Figure 10

\section{SO2 OXIDATION VS. FLOW RATE}

\section{4th QUARTER 1993}

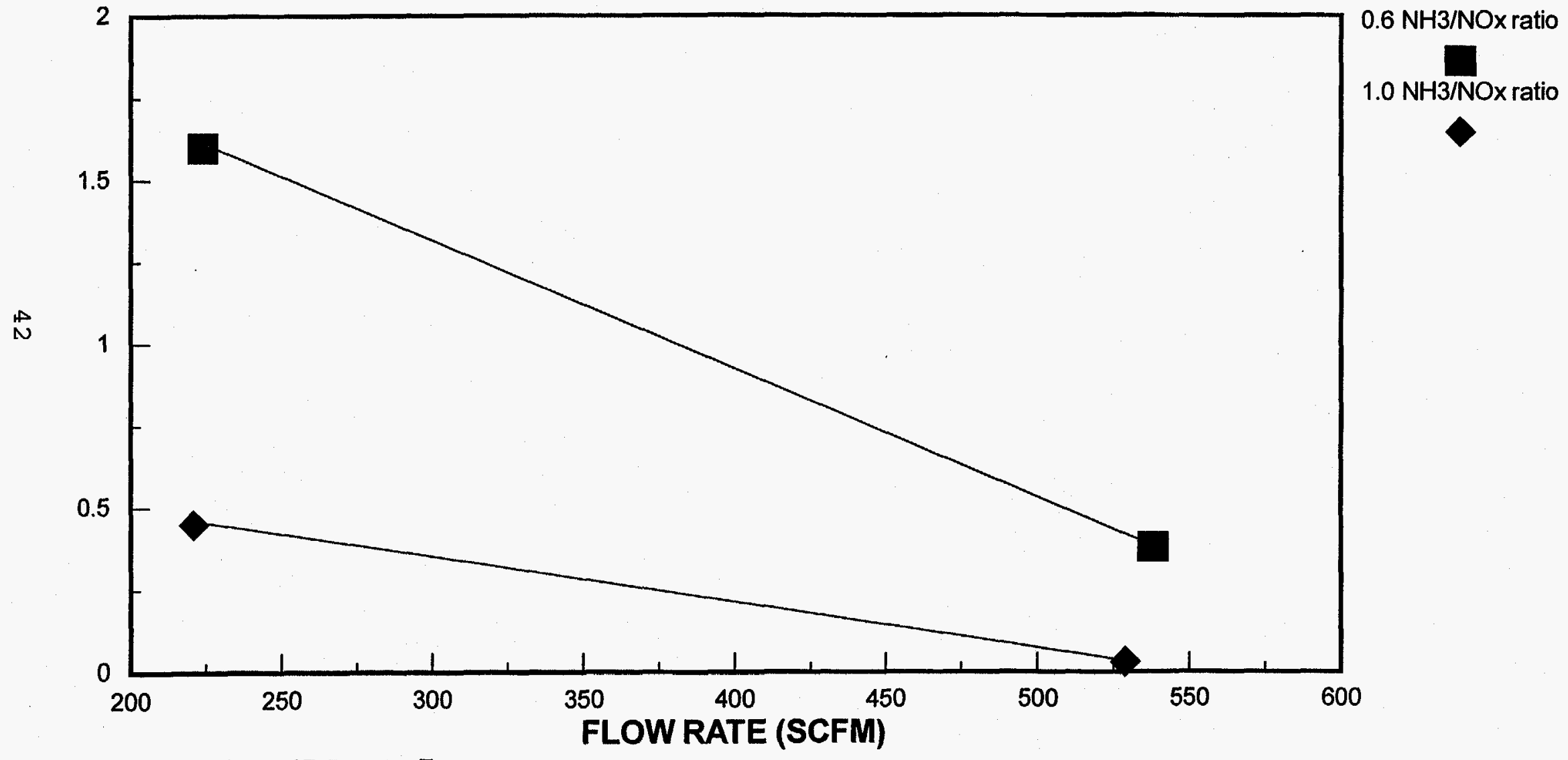

CORMETECH, $750^{\circ} \mathrm{F}$, Reactor E 


\section{Figure 11 \\ SO2 OXIDATION VS. TEMPERATURE}

4th QUARTER 1993

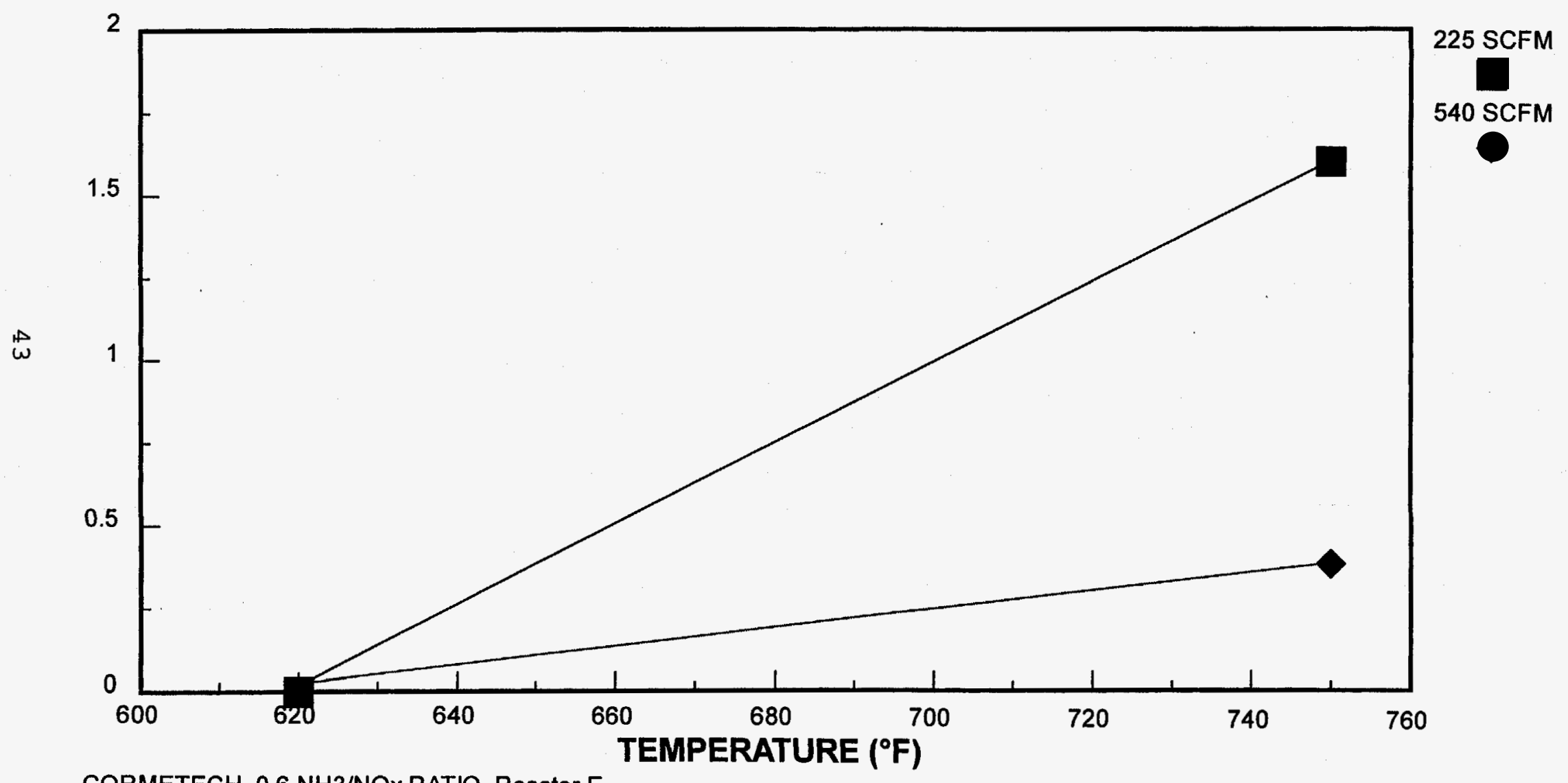

CORMETECH, 0.6 NH3/NOx RATIO, Reactor E 
The pressure drop across the reactor is another important criteria for SCR usage because of its effect on fan horsepower requirements, the single largest energy need for the SCR process. Typical reactor pressure drop is shown in Figure 3.

Mass concentrations and flue gas velocity profiles were conducted at an 84-MW boiler load for the design operating condition $\left(700^{\circ} \mathrm{F}, 100 \%\right.$ flow rate $[400 \mathrm{scfm}]$, and $\mathrm{NH}_{3} / \mathrm{NO}_{\mathrm{x}}$ ratio of 0.8$)$. The mass concentration profile data is given in Figure 12 in four different units of concentration and as mass emission rate. The average mass concentration were $1.34 \mathrm{gr} / \mathrm{acf}, 3.39 \mathrm{gr} / \mathrm{dscf}, 3,070$ $\mathrm{mg} / \mathrm{acm}$, and $7,780 \mathrm{mg} / \mathrm{dscm}$ (with a relative standard deviation of $18 \%$ ); and the average emission rate was $5.72 \mathrm{lb} / \mathrm{MBtu}$. The flue gas velocity profile is presented in Figure 13. The average velocity was $12.0 \pm 2.3 \mathrm{ft} / \mathrm{sec}^{1}$

$\mathrm{HCl}$ concentration was also measured at the design operating condition. The three test results and resulting average $\mathrm{HCl}$ concentration (at $3 \% \mathrm{O}_{2}$, wet) were as follows: ${ }^{1}$

\section{HCl concentration, ppmv}

Sample 1

Sample 2

Sample 3

Average

- Reactor F
203

191

$\underline{187}$

$194 \pm 8.1$

Table 10 shows the performance of the catalyst at or near the design operating conditions of 0.8 ammonia-to- $\mathrm{NO}_{\mathrm{x}}$ ratio, $400 \mathrm{SCFM}$ flow rate, and $700^{\circ} \mathrm{F}$ reactor temperature. As can be seen in the table, the actual measured ammonia-to- $\mathrm{NO}_{\mathrm{x}}$ ratio is greater than 0.8 . This is primarily the result of some miscalibrations in both flow rate and ammonia injection rate, creating a higher than desired ammonia-to- $\mathrm{NO}_{\mathrm{x}}$ ratio. This higher ratio, however, has one beneficial effect in that it creates ammonia slip values that are well within the ammonia sampling method detection range. Slip values measured at 0.8 ammonia-to- $\mathrm{NO}_{\mathrm{x}}$ ratio are expected to be near or below detection limits. Slips within the detection limits allow for more accurate comparisons between catalysts and also allow for more accurate reactor modeling to be performed. Also included in the table is the baseline $\mathrm{SO}_{2}$ oxidation rate and the corresponding reactor conditions for the measurement. Ammonia slip and $\mathrm{SO}_{2}$ oxidation are not typically measured simultaneously and therefore the reactor operating conditions differ slightly for the reported slip and $\mathrm{SO}_{2}$ oxidation values. 
Figure 12. Mass concentration and mass emission rate profiles at the Reactor $E$ outlet. Mass Concentration, gr/acf

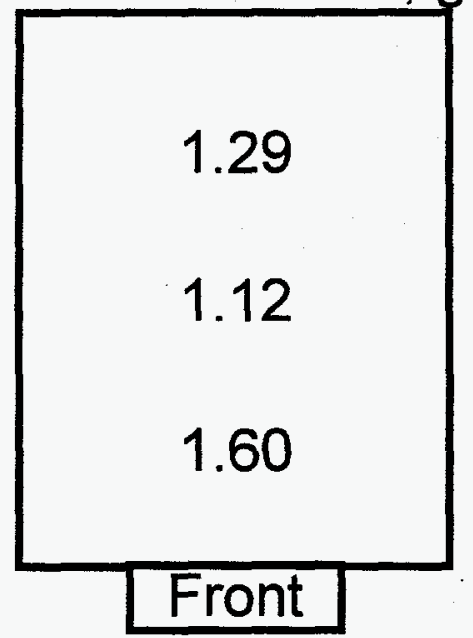

Mass Concentration, gr/dscf

Mass Concentration, $\mathrm{mg} / \mathrm{acm}$
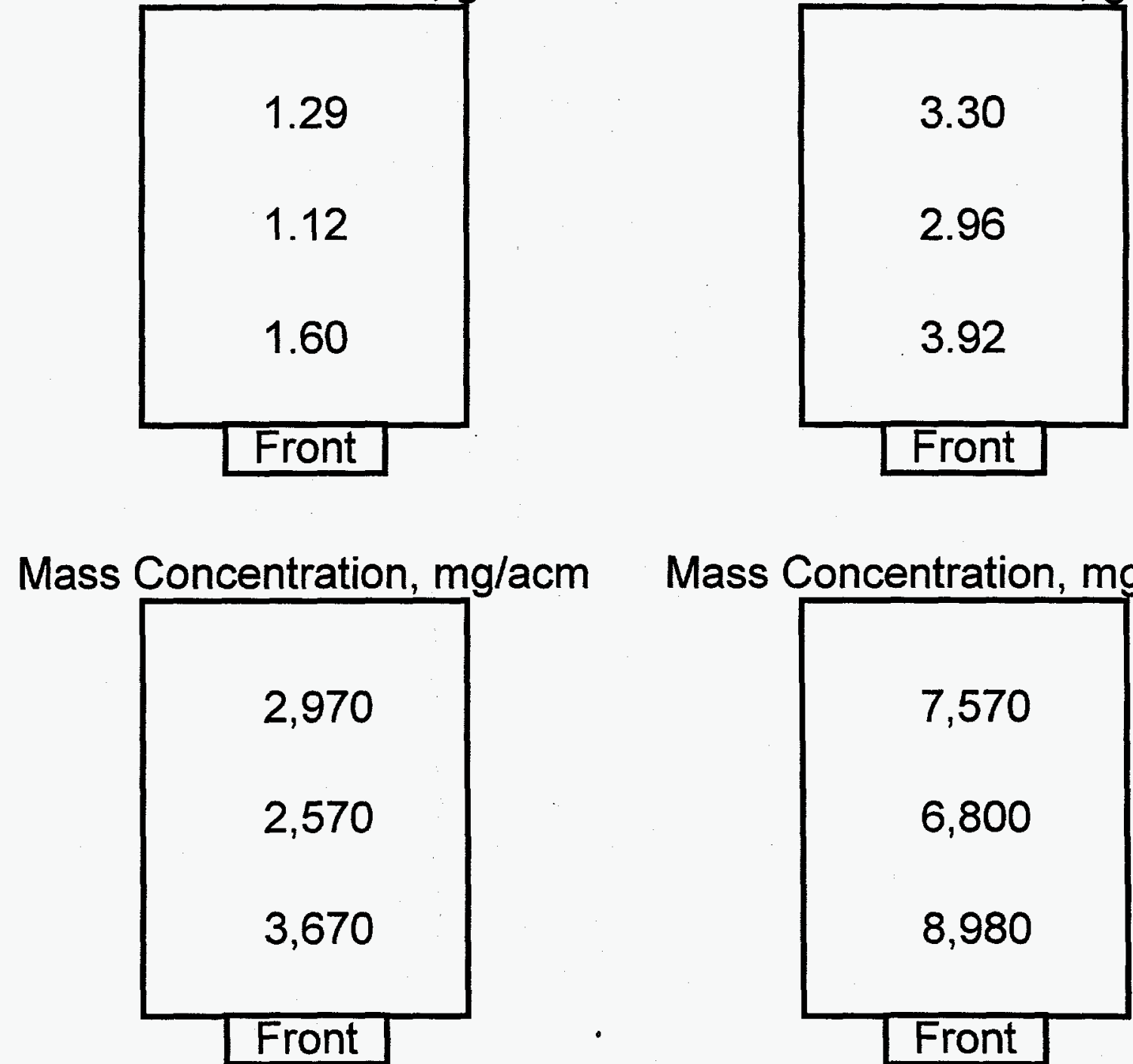

Mass Concentration, $\mathrm{mg} / \mathrm{dscm}$

Mass Emission Rate, Ib/MBtu

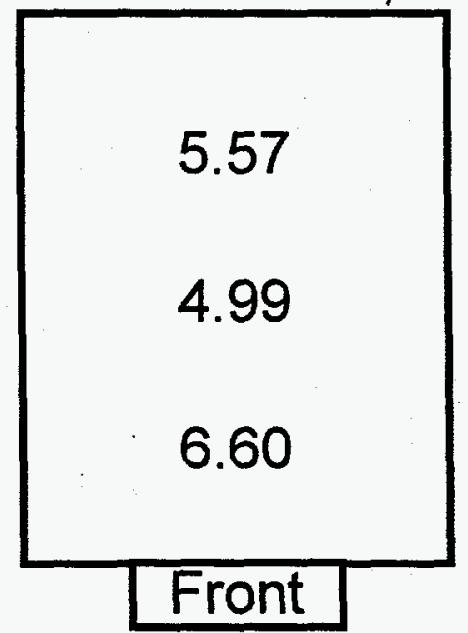


Figure 13. Flue gas velocity profile at the Reactor E outlet.

\section{Flue Gas Velocity, ft/s}

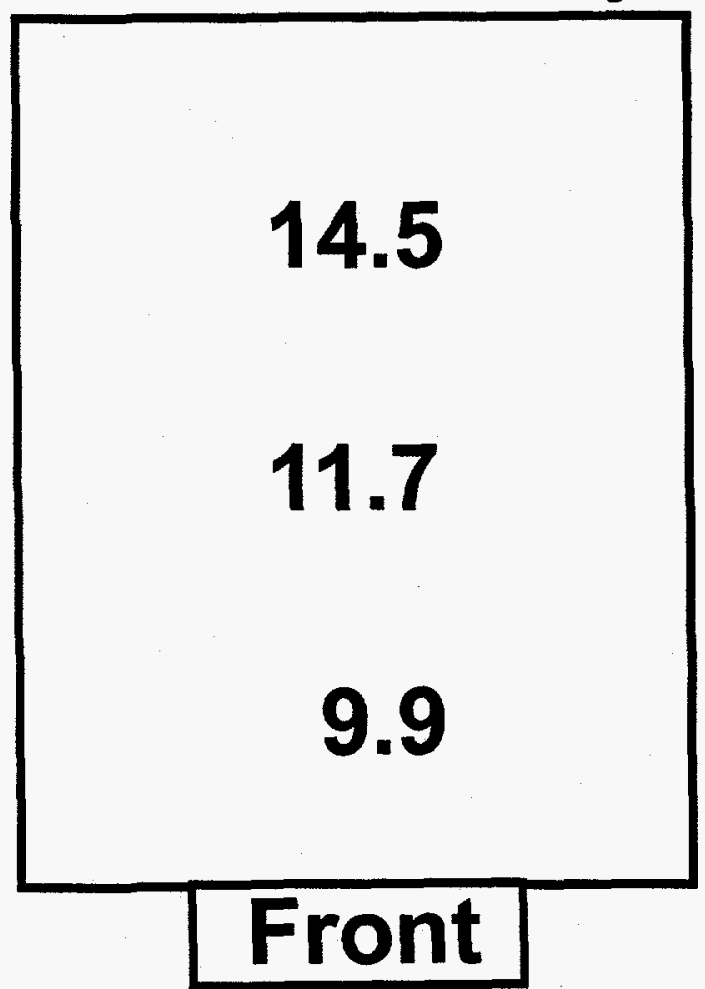




\section{TABLE 10. BASELINE PEREORMANCE}

$\begin{array}{lllllll}\text { Flow } & \text { Temp. } & \mathrm{NO}_{\mathrm{x}} \text { in } & \mathrm{NH}_{3} / \mathrm{NO}_{\mathrm{x}} & \mathrm{NH} 3 \mathrm{Slip} & \mathrm{NO}_{\mathrm{x}} \text { Red. } & \mathrm{SO}_{2} \mathrm{O}_{\mathrm{x}} \\ (\mathrm{SCFM}) & (\mathrm{O}) & \text { (ppmv) } & \text { Ratio } & (\mathrm{ppmv}) & \frac{(\%)}{(\%)} \\ 377 & 700 & 305 & 0.872 & 0.7 & 86 \% & - \\ 373 & 700 & 324 & 0.862 & -- & 84 \% & 0\end{array}$

The majority of the ammonia measurements during the preliminary parametric tests focused on concentrations downstream of the first catalyst bed. These measurements were made as part of a series of statistically designed tests which varied flow rate, temperature, and ammonia-to- $\mathrm{NO}_{\mathrm{x}}$ ratio. Each of these parameters was varied using a high and low value. Thus, eight permutations are created which correspond to the eight test conditions for this portion of the parametric tests. The results of this series of tests are shown as a plot of $\mathrm{NO}_{\mathrm{x}}$ removal across the first catalyst bed versus ammonia-to- $\mathrm{NO}_{\mathrm{x}}$ ratio in Figure 14. Test procedures called for the measurement of ammonia, which is used in the kinetic analyses. The reported $\mathrm{NO}_{\mathrm{x}}$ removals for the plot shown below are computed from the measured ammonia concentration using standard material balance techniques.

Table 11 shows the data used to generate the previous plot. Also included is base line intermediate ammonia data. The data are presented in terms of intermediate ammonia concentrations, which is the measured parameter. All data is corrected to reactor inlet oxygen concentrations.

\section{TABLE 11. INTERMEDIATE AMMONIA PARAMETRIC TEST DATA}

$\begin{array}{lllllc}\begin{array}{l}\text { Flow Rate } \\ (\mathrm{SCFM})\end{array} & \begin{array}{l}\text { Temp. } \\ \mathbf{( \circ \mathrm { F } )}\end{array} & \begin{array}{l}\text { Inlet } \mathrm{O}_{2} \\ (\%)\end{array} & \begin{array}{l}\text { Inlet } \mathrm{NO}_{\mathbf{x}} \\ \text { (ppmv) }\end{array} & \begin{array}{l}\mathrm{NH}_{3} / \mathrm{NO}_{\mathbf{x}} \\ \text { Ratio }\end{array} & \begin{array}{c}\text { Int. } \mathrm{NH}_{3} \\ \text { (ppmv) }\end{array} \\ 223 & 620 & 3.512 & 300 & 0.700 & 5.2 \\ 557 & 620 & 3.265 & 315 & 1.098 & 21.6 \\ 554 & 620 & 4.913 & 290 & 0.656 & 33.7 \\ 368 & 620 & 2.166 & 310 & 1.015 & 98.8 \\ 224 & 700 & 3.248 & 290 & 0.887 & 30.9 \\ 226 & 750 & 6.218 & 325 & 0.663 & 4.4 \\ 554 & 750 & 3.732 & 271 & 1.144 & 11.7 \\ 555 & 750 & 6.123 & 199 & 0.980 & 28.1 \\ & 750 & 1.867 & 289 & 1.068 & 75.9\end{array}$




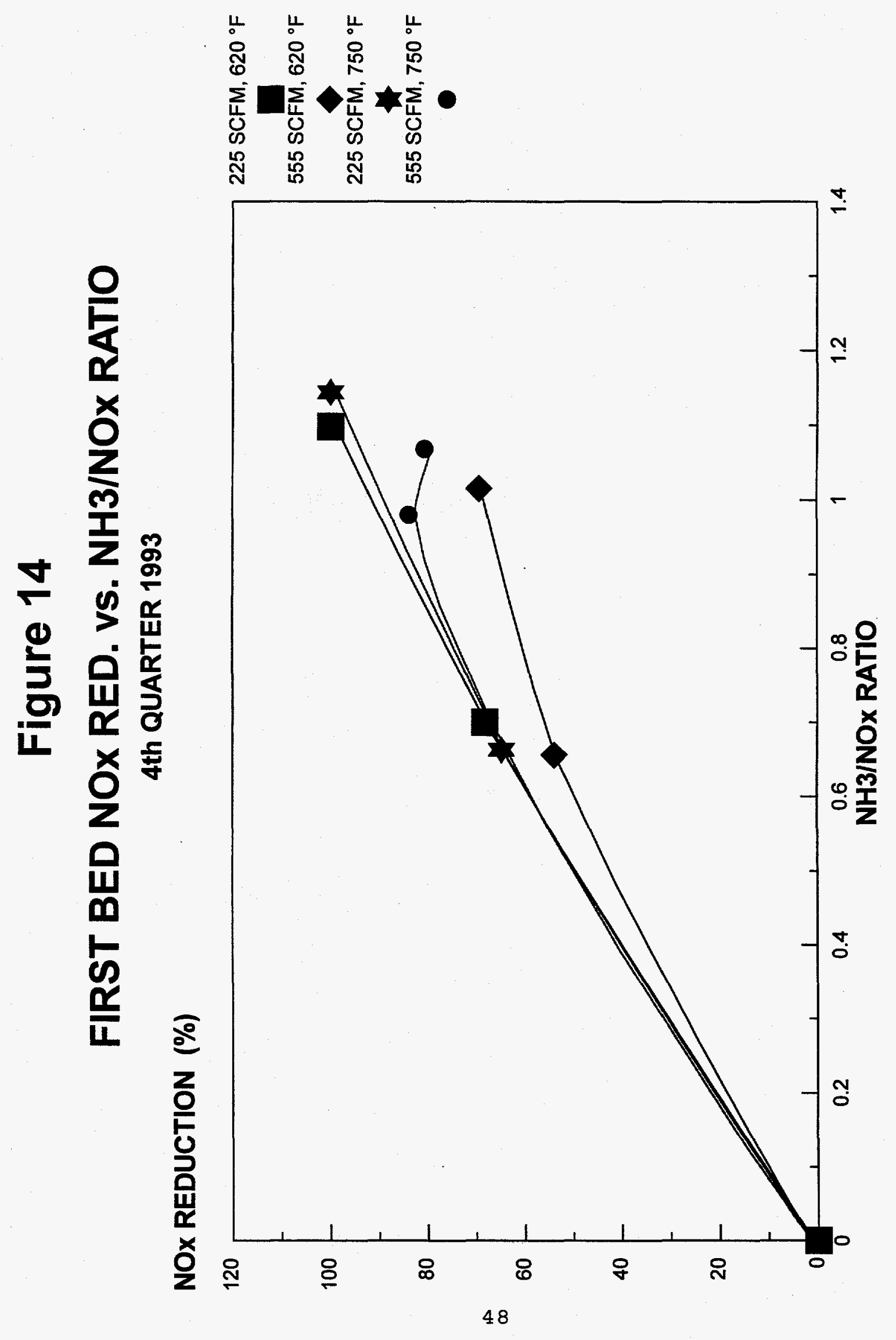


Parametric tests were also performed to determine the sulfur dioxide oxidation characteristics of the catalyst. The operating parameters of the reactor were varied in an identical fashion to the intermediate ammonia parametric tests. Thus, eight specific parametric tests were performed in addition to the base line test. The data is presented in two plots, Figure 15 one showing the effect of flow rate on sulfur dioxide oxidation, and Figure 16 one showing the effect of temperature on sulfur dioxide oxidation. The flow rate effect data is based on high temperature data, with two lines shown, one for high ammonia-to- $\mathrm{NO}_{\mathrm{x}}$ ratio, and one for low ammonia-to$\mathrm{NO}_{\mathrm{x}}$ ratio. The temperature effect is based on low ammonia-to- $\mathrm{NO}_{\mathrm{x}}$ ratio data, with two lines shown, one for high flow rate, and one for low flow rate. The plots show a definite ammonia-to$\mathrm{NO}_{\mathrm{x}}$ ratio effect on the sulfur dioxide oxidation characteristics of the catalyst. However, this effect is not thought to be a true catalytic effect, but is actually a precipitation effect. Earlier studies with no catalyst present showed that sulfur trioxide was lost through the reactor, most likely in cold spots such as test ports, etc. The presence of ammonia may affect this precipitation phenomenon. Most likely this occurs by changing the precipitation characteristics of the sulfur trioxide through the formation of byproducts such as ammonium bisulfate in the cold spots of the reactor.

Similar to the previously shown table of intermediate ammonia data, Table 12 shows the sulfur dioxide oxidation data for each of the parametric conditions that were tested. This data is corrected to reactor outlet oxygen concentrations. The value for sulfur trioxide produced in the reactor is based on the measured outlet sulfur trioxide concentration and estimated sulfur trioxide reactor inlet values. The reactor inlet sulfur trioxide values are estimated using past measurements of inlet sulfur trioxide based on host boiler load. In many cases, especially those involving low temperature conditions, there was no net increase in sulfur trioxide concentrations across the reactor. In fact, some operating conditions showed a loss in sulfur trioxide across the reactor in addition to the loss that normally occurs without catalyst present. In these cases, the sulfur dioxide oxidation rate is taken to be zero. (Tables showing $\mathrm{SO}_{2}$ oxidation rates quote reactor flow rates as calculated for the reactor exit, since $\mathrm{SO}_{3}$ is measured at this point. For consistency with other figures, the plots of $\mathrm{SO}_{2}$ oxidation versus flowrate are based on reactor inlet flowrates. In practice, differences between inlet and outlet flowrates are slight and do not greatly affect the overall analysis.) 


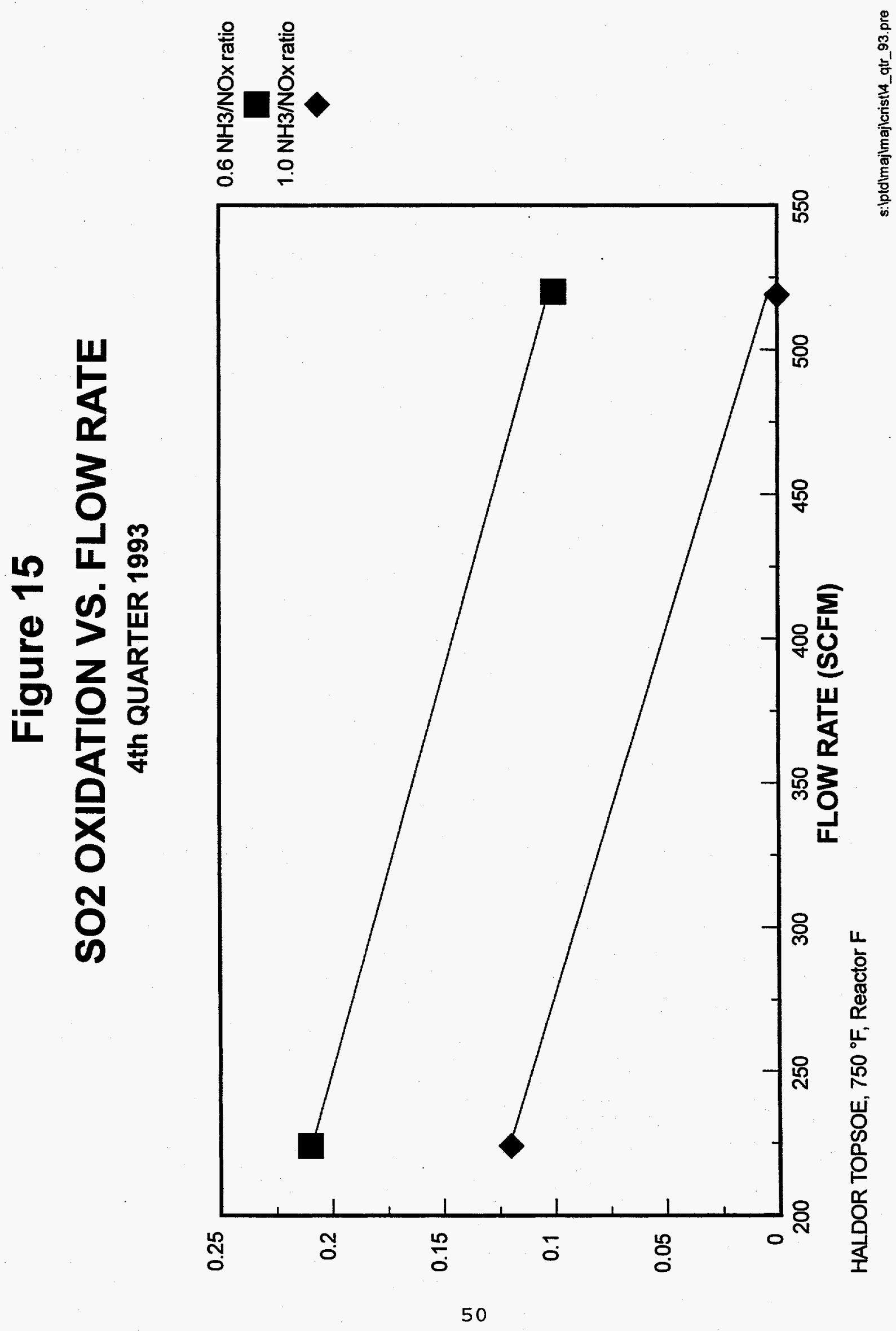




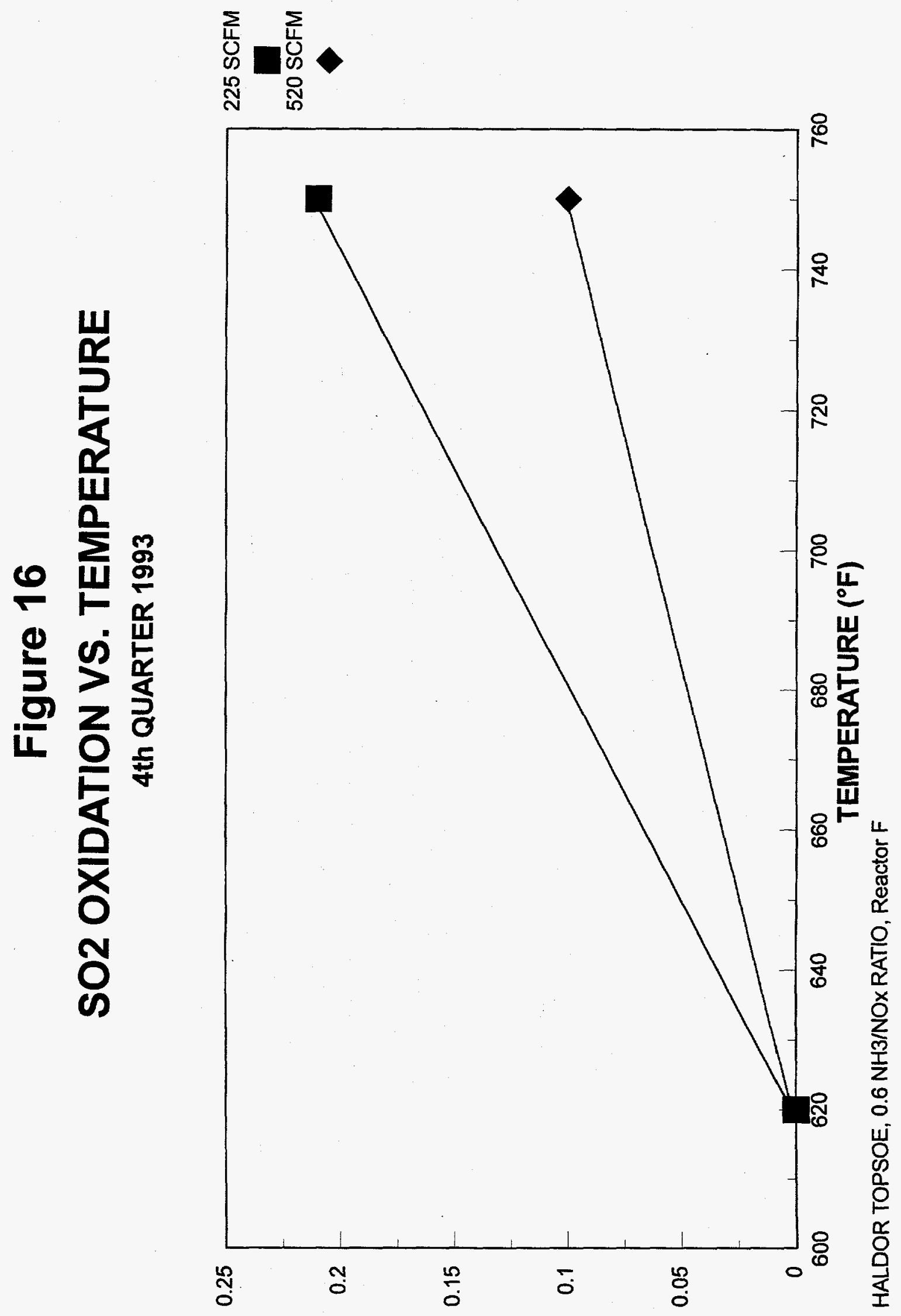




\section{TABLE 12. SULFUR DIOXIDE OXIDATION PARAMETRIC TEST DATA}

\begin{tabular}{|c|c|c|c|c|c|c|c|c|}
\hline $\begin{array}{l}\text { Flow } \\
\text { Rate } \\
\text { (SCFM) } \\
\end{array}$ & $\begin{array}{l}\text { Operating } \\
\text { Temp. } \\
\left(^{\circ} \mathrm{F}\right)\end{array}$ & $\begin{array}{l}\text { Outlet } \\
\mathrm{O}_{2} \\
(\%)\end{array}$ & $\begin{array}{l}\text { Inlet } \\
\mathrm{SO}_{2} \\
\text { (ppmv) }\end{array}$ & $\begin{array}{l}\mathrm{NH}_{3} / \\
\mathrm{NO}_{\mathrm{x}} \\
\text { Ratio } \\
\end{array}$ & $\begin{array}{l}\mathrm{SO}_{3} \\
\text { formed } \\
\text { (ppmv) }\end{array}$ & $\begin{array}{l}\text { Predicted/ } \\
\mathrm{SO}_{3} \text { in } \\
\text { (ppmv) }\end{array}$ & $\begin{array}{l}\text { Measured/ } \\
\mathrm{SO}_{3} \text { out } \\
\text { (ppmv) }\end{array}$ & $\begin{array}{l}\text { Oxid. } \\
\text { Rate } \\
(\%)\end{array}$ \\
\hline 201 & 620 & 3.696 & 2013 & 0.791 & -4 & 6.9 & 3.2 & 0 \\
\hline 237 & 750 & 3.833 & 2202 & 0.674 & 4 & 6.6 & 10.9 & 0.21 \\
\hline 237 & 750 & 3.887 & 2177 & 1.124 & 3 & 6.6 & 9.1 & 0.12 \\
\hline 538 & 750 & 2.930 & 1868 & 0.656 & 2 & 7.2 & 9.1 & 0.10 \\
\hline 538 & 750 & 3.687 & 1757 & 1.094 & -2 & 8.4 & 6.7 & 0 \\
\hline
\end{tabular}

The pressure drop across the reactor is another important criteria for SCR usage because of its effect on fan horsepower requirements, the single largest energy need for the SCR process. Typical reactor pressure drop is shown in Figure 3.

Mass concentrations and flue gas velocity profiles were conducted at an 84-MW boiler load for the design operating condition $\left(700^{\circ} \mathrm{F}, 100 \%\right.$ flow rate $[400 \mathrm{scfm}]$, and $\mathrm{NH}_{3} / \mathrm{NO}_{\mathrm{x}}$ ratio of 0.8$)$. The mass concentration profile data is given in Figure 17 in four different units of concentration and as mass emission rate. The average mass concentration were $1.58 \mathrm{gr} / \mathrm{acf}, 4.01 \mathrm{gr} / \mathrm{dscf}, 3,630$ $\mathrm{mg} / \mathrm{acm}$, and $9,180 \mathrm{mg} / \mathrm{dscm}$ (with a relative standard deviation of $13.5 \%$ ); and the average emission rate was $6.75 \mathrm{lb} / \mathrm{MBtu}$. The flue gas velocity profile is presented in Figure 18 . The average velocity was $13.1 \pm 0.87 \mathrm{ft} / \mathrm{sec}^{1}$

$\mathrm{HCl}$ concentration was also measured at the design operating condition. The three test results and resulting average $\mathrm{HCl}$ concentration (at $3 \% \mathrm{O}_{2}$, wet) were as follows: ${ }^{1}$

\section{$\underline{\mathrm{HCl} \text { concentration, } \mathrm{ppmv}}$}

Sample 1 191

Sample 2 188

Sample 3

$\underline{178}$

Average

$186 \pm 6.6$ 
Figure 17. Mass concentration and mass emission rate profiles at the Reactor $F$ outlet. Mass Concentration, gr/acf

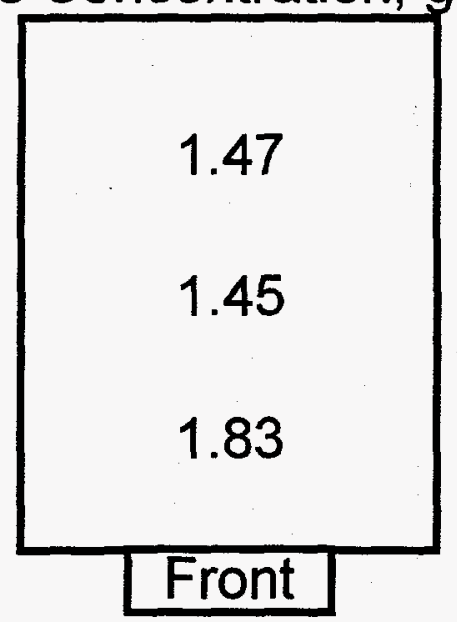

Mass Concentration, gr/dscf

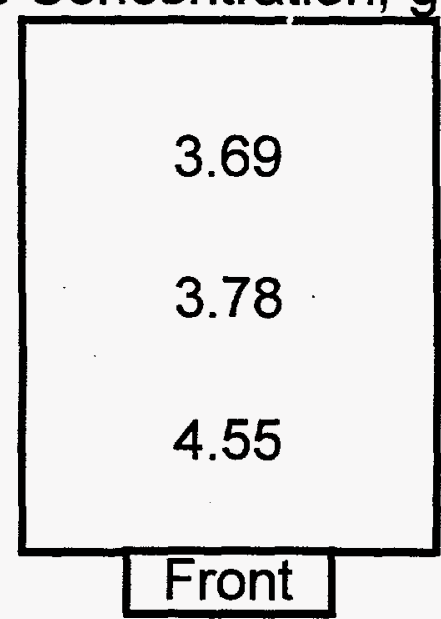

Mass Concentration, $\mathrm{mg} / \mathrm{acm}$

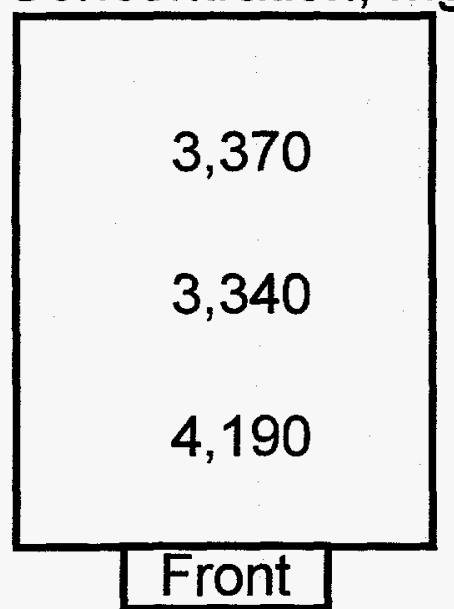

Mass Concentration, $\mathrm{mg} / \mathrm{dscm}$

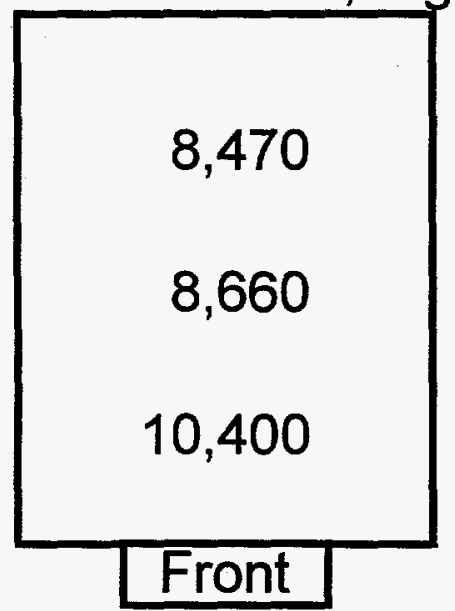

Mass Emission Rate, Ib/MBtu

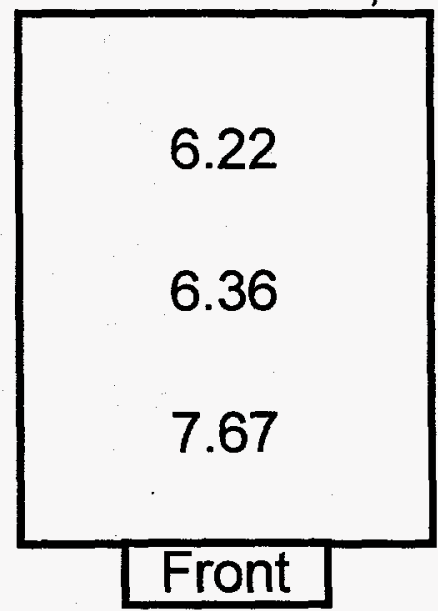


Figure 18. Flue gas velocity profile at the Reactor $\mathrm{F}$ outlet.

\section{Flue Gas Velocity, ft/s}

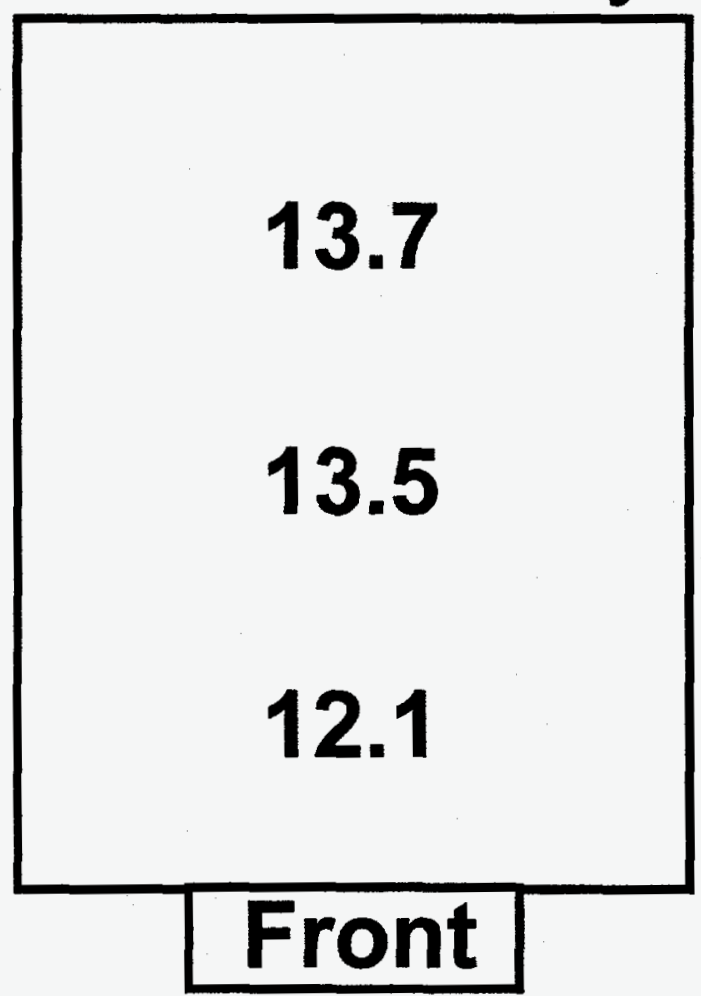




\section{Task 1.3.6 - Project Management and Reporting}

The Management Information System, developed for tracking overall budget and schedule information, was used to monitor budget and schedule and to help fulfill DOE reporting requirements. Monthly progress reports were submitted to DOE.

A project review meeting was held for all involved parties on December 8-9 at Plant Crist in which general progress since September 1993 was discussed, and specific vendor data were discussed in separate meetings with each vendor.

The Continuation Application and request for additional funds, which were previously submitted to DOE, were approved and contract modifications reflecting this approval were initiated. The Continuation Application requested DOE's approval for matching funds of Budget Period 2 to continue the project to completion. Budget Period 2 provides DOE funding for Phase III, which includes operations, testing, disposition, and final report. 


\section{Section 5 \\ PLANNED ACTIVITIES}

During the first two quarters of 1994 , the following activities are planned:

- Complete the next set of parametric tests on all reactors/catalysts. Meanwhile, continue operations at long term conditions for the reactors/catalysts when not undergoing parametric testing.

- Take catalyst samples and submit for laboratory analysis.

- Install replacement catalyst for Reactor $\mathrm{G}$ and the replacement sampling coupons for Reactors $\mathrm{F}$ and $\mathrm{G}$.

- Replace the ammonia flow controllers for the large reactors and continue efforts to resolve problems with the continuous $\mathrm{NO}_{\mathrm{x}}$ measuring system for the intermediate bed levels (with ammonia present).

- Perform evaluation and select and install replacement catalysts for Reactors $\mathrm{H}$ and $\mathrm{J}$.

- $\quad$ Hold status meeting in May 1994. 


\section{REFERENCES}

1. Testing and Analytical Services for the Innovative Clean Coal Technology Demonstration of Selective Catalytic Reduction (SCR) Technology for the Control of Nitrogen Oxide (NO ${ }_{\mathbb{X}}$ ) Emissions from High Sulfur Coal, Final Report for Task 3. Parts 4 - 6. Preliminary Parametric Tests, Draft SRI report to SCS. 